\title{
The Impact of Climate Change on Crop Production in Uganda-An Integrated Systems Assessment with Water and Energy Implications
}

\author{
Vignesh Sridharan ${ }^{1, *}$, Eunice Pereira Ramos ${ }^{1}$, Eduardo Zepeda ${ }^{2}$, Brent Boehlert ${ }^{3}$, \\ Abhishek Shivakumar ${ }^{1,2}$, Constantinos Taliotis ${ }^{4}$ (D) and Mark Howells ${ }^{1}$ \\ 1 KTH-Royal Institute of Technology, Unit of Energy Systems Analysis, Brinellvägen 68, Stockholm 10044, Sweden \\ 2 United Nations Department of Economic and Social Affairs (UNDESA), Development Policy and Analysis \\ Division, 405 East 42nd Street, New York, NY 10017, USA \\ 3 Industrial Economics Inc., 2067 Massachusetts Ave, Cambridge, MA 02140, USA \\ 4 The Cyprus Institute, 20 Konstantinou Kavafi Street, Aglantzia, Nicosia 2121, Cyprus \\ * Correspondence: vsri@kth.se
}

Received: 5 July 2019; Accepted: 22 August 2019; Published: 29 August 2019

\begin{abstract}
With less than 3\% of agricultural cropland under irrigation, subsistence farmers in Uganda are dependent on seasonal precipitation for crop production. The majority of crops grown in the country - especially staple food crops like Matooke (Plantains) - are sensitive to the availability of water throughout their growing period and hence vulnerable to climatic impacts. In response to these challenges, the Government has developed an ambitious irrigation master plan. However, the energy implications of implementing the plan have not been explored in detail. This article attempts to address three main issues involving the nexus between water, energy, crop production, and climate. The first one explores the impact of climate on rain-fed crop production. The second explores the irrigation crop water needs under selected climate scenarios. The third focuses on the energy implications of implementing the irrigation master plan. We attempt to answer the above questions using a water balance model for Uganda developed for this study. Our results, developed at a catchment level, indicate that on average there could be an $11 \%$ reduction and $8 \%$ increase in rain-fed crop production in the cumulatively driest and wettest climates, respectively. Furthermore, in the identified driest climate, the electricity required for pumping water is expected to increase by $12 \%$ on average compared to the base scenario.
\end{abstract}

Keywords: climate change; crop yield; irrigation; pumping electricity demand; Uganda; integrated analysis

\section{Introduction}

With a significant share (72\%) of the Ugandan population employed in agricultural activities and the sector contributing to about $21.5 \%$ of the GDP in 2017, it is expected to be the backbone of the economy for the foreseeable future [1]. About $46 \%$ of Ugandan export earnings can be attributed to the agricultural sector; coffee, tea, cotton, and tobacco constitute a significant share of the total exports [2], whereas, based on the area under cultivation, plantains (Matooke bananas), cassava, maize, and sorghum are some of the major crops. The majority of the farming in Uganda is on a subsistence basis. Despite the rise in commercial farming for lucrative export markets, their share in total production is low. More than $95 \%$ of the cultivated crops in the country is rain-fed. In 2012, an area of approximately $140 \mathrm{~km}^{2}$ was irrigated [3]. This high dependence on seasonal rainfall places crop production and the nation's food security at a higher risk. Based on historical records, Mburu et al. [4] conclude that the onset of rainfall has shifted by a month in some regions of Uganda with no change to dates of cessation, potentially leading to change in cropping patterns. There is a consensus amongst the 
literature on the impact of climate on rain-fed crop production in Sub-Saharan Africa (SSA); it projects a bleak outlook for the majority of staple crops [5-7]. With a high share of rain-fed cultivation, Ugandan crop production is more exposed to climatic variability than its neighbors in the Eastern African region. All the Matooke (plantains), cassava, sorghum, and more than $90 \%$ of the maize produced in the country are not irrigated and hence vulnerable to climatic changes.

In the past, different methodologies have been employed to assess the climatic impact on crop production (both rain-fed and irrigated), each with its contributions and limitations. Wasige et al. were probably the first to classify Uganda into agro-ecological zones and analyze the climatic crop yield impact [8]. Bagamba et al. [9] describe a method using a statistical model (the tradeoff analysis model for multi-dimensional impact assessment (TOAMD)) to analyze historical data and derive relations. The model, though based on sound statistical principles, does not offer any spatial insights. Waithaka et al. [10] and Dale et al. [11] present the modelling results from the International Model for Policy Analysis of Agricultural Commodities and Trade (IMPACT) developed by the International Food Policy Research Institute (IFPRI). They provide good district level detail on yield variations under different emission scenarios, but they do not evaluate main staple crops like Matooke, which pose a higher food security risk than cash crops like coffee and tea. Villegas and Thornton [6] use the results derived from an EcoCrop model to give broad indications on the impact of climate on nine major crops in the African continent. They chose five general circulation models (GCMs) and explored two representative concentration pathways (RCPs) $\left(4.5\right.$ and $\left.8.5 \mathrm{~W} / \mathrm{m}^{2}\right)$. The above literature is only a small selection and there exist many more studies that try to approach the problem from different scientific and institutional perspectives. However, none of them explores the different extremes (not to be confused with extreme events like droughts and floods) that could be realized from the set of climate projections available under the Coupled Model Inter-Comparison Project (CMIP5) umbrella. The methodology developed for this analysis explores the gap mentioned above by taking into consideration the scenarios of extreme water availability from the available CMIP5 projections.

To address the growing food production concerns arising due to the climate, resource distribution, and management practices, to name a few, the government introduced an irrigation master plan $[2,12]$ to be effective until 2035. The master plan provides a detailed technical pathway for irrigation infrastructure but does not discuss the energy implications of irrigating a large portion of the cultivatable land. Additionally, water availability under different climates will play a key role in determining the energy demand for irrigation. An arid future will increase crop water needs and hence increased pumping activity for irrigation. Hence, the master plan, though detailed on agricultural aspects, does not explore the interactions between the water-energy-food (WEF) systems, which this analysis aims to achieve.

Implementing policies in one sector (water, agriculture, energy, etc.) without taking into consideration the interactions and propagation effects on other interlinked sectors could lead to lopsided decisions, as demonstrated in different case studies [13-16]. In the last decade, the nexus between the WEF systems and inter-sectorial policymaking has gained traction [17-21]. In the Ugandan context, there have been some national level nexus assessments $[22,23]$ that explore the intersectoral synergies and tradeoffs in the country.

Under the larger umbrella of the WEF nexus, we attempt to shed some light on two research areas, first, on the climatic impact on rain-fed crop production in Uganda, taking into consideration a baseline and a set of dry and wet climate futures. The second focus is on an initial estimate of the pumping energy demand (for irrigation) - under different climates—taking into consideration site-specific crop water requirements, water table depth, and some limitations that arise from the non-availability of granular data.

A combination of GIS routines and a WEAP (water evaluation and planning tool) model developed for the region are used to highlight that despite the cumulative decrease in crop production under a dry climate and vice-versa, yearly variations will play a critical role in meeting local demands and minimum dietary requirements in the country. We estimate crop and catchment specific production changes for the analyzed climatic futures along with the energy demand for pumping water. 


\section{Materials and Methods}

\subsection{Study Area}

This study considered the Ugandan national border as its boundary for the crop production analysis. However, there was also a need to include areas outside its national borders. About 35\% of the total yearly renewable water resource in Uganda comes from outside its national borders [24]. Most of the catchments that drain into Lake Victoria lie outside Ugandan borders-in Tanzania, Kenya, Rwanda, and Burundi [25]. In addition to the drainage area of Lake Victoria, there are other shared catchments with the Democratic Republic of the Congo that needed to be taken into consideration. Hence, as illustrated in Figure 1 (below), the entire study area was comprised of land and water bodies inside Ugandan national borders along with outer regions that contribute to the renewable water resource in Uganda.

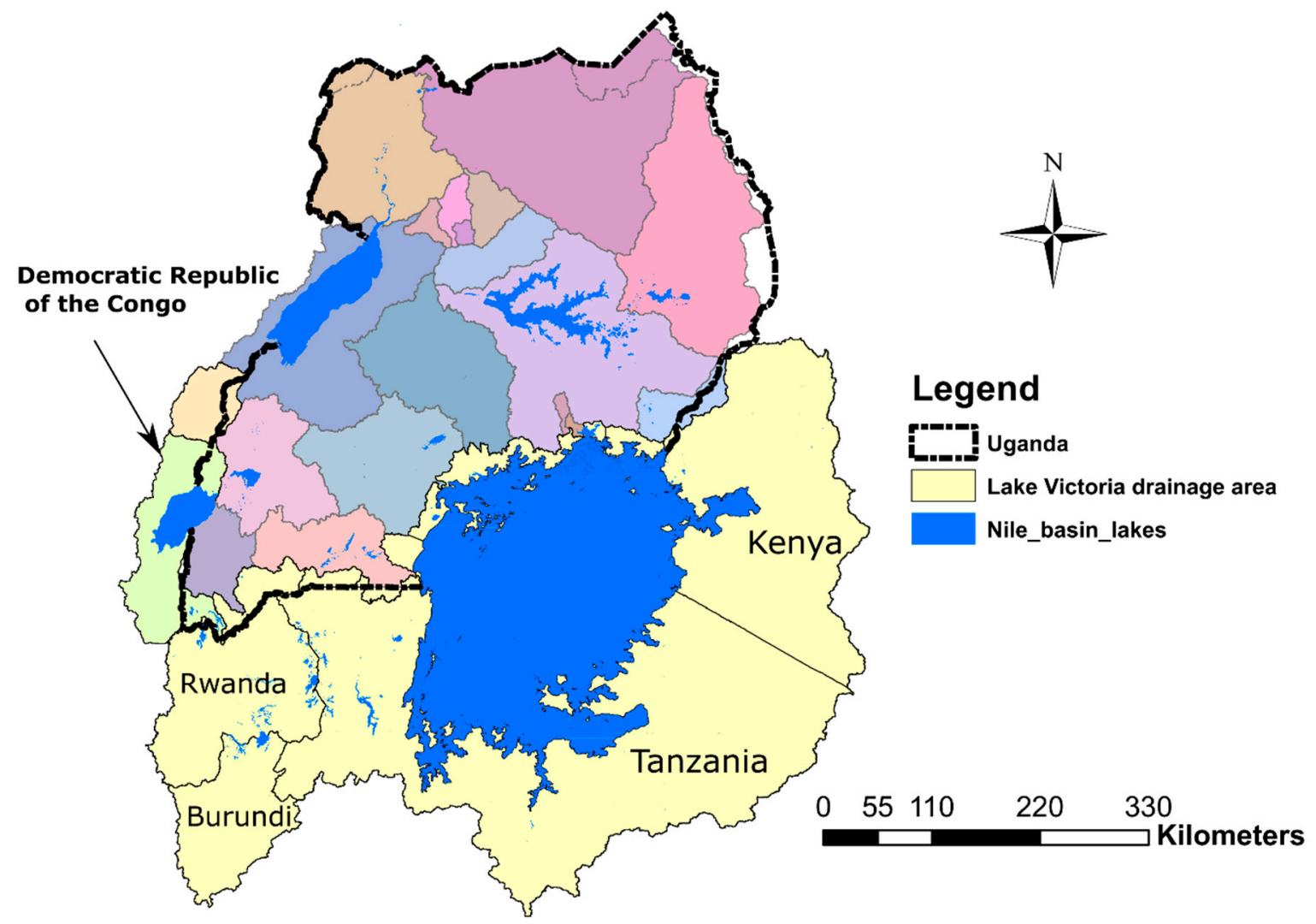

Figure 1. Study area.

With an average elevation of about $1300 \mathrm{~m}$ above sea level, Uganda is a warm tropical country with average temperatures ranging between 18 and 30 degree Celsius. The average annual precipitation in Uganda ranges from $500 \mathrm{~mm}$ in the arid northeastern Karamoja region to above $2000 \mathrm{~mm}$ in some areas surrounding Lake Victoria. The eastern and western fronts of the East African Rift valley system and the equatorial lakes affect the regional climate significantly [26]. Most parts of Uganda experience two wet seasons-one between April and May and another from August to October. The arid northeastern region receives one pronounced rainy season between August and October [27]. It is also important to note that the region also experiences higher evapotranspiration rates. The reference evapotranspiration $\left(E T_{0}\right)$ is twice the average rate of precipitation in the northeastern part of Uganda. Hence, soil moisture is expected to play a critical role during dry spells. From a crop production point of view, Matooke (plantain banana), cassava, maize, and sorghum are some of the major staple crops in the country [28]. As of 2017, they were also the most harvested crops by area [29]. Uganda has abundant groundwater 
reserves [27]. The average water table depth (WTD) is approximately $23 \mathrm{~m}$, although it ranges from wetlands (WTD $=0$ ) to regions in the southwest of the country with an average WTD of $\sim 400 \mathrm{~m}$.

\subsection{Model Setup and Methodology}

In this analysis, we used the water evaluation and planning tool (WEAP), developed by the Stockholm Environmental Institute (SEI) [30] to explore the climatic impact on crop production. WEAP is a hydrological water system management framework, which has been refined over the past 20 years, and is utilized by thousands of registered users from over 170 countries [31]. It is a multi-purpose tool effectively applied to explore hydrological water balances, water withdrawal and consumption in the power sector, crop production, groundwater management, and climate change impacts, to name a few applications [32-37]. Despite the existence of dedicated tools to develop crop yield analysis, like Aquacrop [38] and Decision support system for agrotechnology transfer (DSSAT) models [39], WEAP was used, owing to its ability to model climatic impacts on crop production, and simultaneously represent land-use change and consider water utilization in other sectors, namely energy, industry, and consumption in households. WEAP's capability to analyze the different CLEW (climate, land, energy, and water) systems made it an ideal tool for this analysis. We used the 'soil-moisture rainfall-runoff method' in WEAP for this analysis. The rate of evapotranspiration was higher than precipitation in some parts of the country, hence the need to represent soil moisture in the model. The model has a monthly temporal resolution and runs until 2050.

\subsubsection{Catchment and Land Cover Classification}

The catchments represented in this WEAP model are classified into two types: areas that contribute to the flow in Ugandan rivers, and areas that drain into Lake Victoria (outside Ugandan borders). Since the focus of this study was to assess the climate-induced crop yield vulnerability inside Uganda, greater spatial detail was used to represent the areas that drain into Ugandan rivers (like Victoria Nile, Kyoga Nile, Albert Nile, Semilki, Aswa, etc.) than for the catchments that drain into Lake Victoria (that lie in Tanzania, Kenya, Burundi, and Rwanda). Thus, a lumped catchment-type water balance model [40-42] was developed for the catchments that drain into Lake Victoria. This lumped catchment was classified into two hydrological nodes: one to represent non-irrigated and another for irrigated areas. The non-irrigated node was further disaggregated into grassland, forestland, wetland, cultivated land, water bodies, and built-up land. The irrigated node represented solely the agricultural area for crop cultivation that is irrigated.

On the contrary, in need for detail, a semi-distributed type model was developed to represent areas that drain into rivers inside Ugandan borders. Each sub-catchment was again disaggregated into non-irrigated and irrigated areas. Table A1 in the Appendix details the classification of non-irrigated areas in the different sub-catchments and their respective areas. Uganda is one of the Sub-Saharan African (SSA) countries experiencing a significant change in land cover [43]. The total forested area in the country has dropped from $\sim 5$ million ha in 1990 to 2 million ha in 2015 [44]. In the past, the expansion of agricultural land for crop production and livestock grazing has been a significant driver of the change in land cover. Hence, to represent this change in agricultural land cover (with a focus on crop cultivation), we disaggregated the cultivated area into eight categories: seven major crops represented individually and the others combined into one group. These crops were chosen based on their harvested areas, production value, and their categorization as a staple food. Four primary sources were used to arrive at catchment specific crop splits:

1. National Water resource assessment (NWRA) report, 2013 [27]

2. Uganda census of agriculture, crop area, and productivity, 2008/2009 [45]

3. FAO Aquastat-Uganda Country Statistics, 2018 [24]

4. National Irrigation master plan (NIMP), 2010-2035 [12] 
The census [45] provides district-specific statistics on crop yields and harvested area, which was used to derive the final share of cultivated area per crop and region. The census was prepared using an older classification of districts, which was appropriated to the new district classification. Finally, region-specific crop shares were derived by overlaying the respective GIS layers and appropriate regional aggregation (Table 1).

Table 1. Cultivated crop shares per region.

\begin{tabular}{ccccc}
\hline Crop classification & Western & Eastern & Central & Northern \\
\hline Plantain banana & $35.2 \%$ & $4.6 \%$ & $32.3 \%$ & $0.6 \%$ \\
Coffee & $3.6 \%$ & $3.1 \%$ & $9.2 \%$ & $0.2 \%$ \\
Maize & $13.0 \%$ & $25.7 \%$ & $18.8 \%$ & $16.4 \%$ \\
Sorghum & $3.2 \%$ & $6.7 \%$ & $0.2 \%$ & $16.5 \%$ \\
Rice & $0.7 \%$ & $2.4 \%$ & $0.3 \%$ & $1.7 \%$ \\
Cassava & $9.0 \%$ & $22.6 \%$ & $12.7 \%$ & $17.9 \%$ \\
Sugarcane & $0.2 \%$ & $0.5 \%$ & $0.8 \%$ & $0.3 \%$ \\
Others & $35.2 \%$ & $33.5 \%$ & $25.7 \%$ & $46.5 \%$ \\
\hline
\end{tabular}

The representation of irrigated areas in this analysis was based on the National irrigation master plan (NIMP) from the Ministry of Water and Environment (MWE). The NIMP provides district-specific irrigation potential and classifies them into two types:

- Type A: Land that lies close to surface water resources on which agricultural water can be managed without the need for storage.

- Type B: Land that does not lie close to surface water resources or which cannot be fully developed in the absence of storage facilities.

Table A2 provides the catchment specific irrigation potential used for this analysis. Some adjacent watersheds with low irrigation potential were joined for the ease of representation. According to the master plan, it was assumed that $70 \%$ of Type A and $20 \%$ of Type B lands will be irrigated by 2035 . Since the model runs until 2050, we assumed that the country will irrigate $100 \%$ of its Type A lands and $70 \%$ of the Type B lands by the end of the modelling period. As indicated in the NWRA, we considered four major crops that are under irrigation schemes in Uganda: rice, maize, sugarcane, and vegetables. For this analysis, it was assumed that the share of irrigated area per crop (per catchment) will remain the same until the end of the modelling period, while the total irrigated area will increase. Crop-specific coefficients $(K c)$ and potential yields were obtained from NIMP [12], NWRA [27], and FAO Aquastat [24]. The potential yield for non-irrigated crops is the average value of actual crop yields (1961-2009) in the country from Aquastat [24]. Since this analysis focused on the yield variations caused by climate-induced water stress, the yield response factors $(K y)$ from the FAO-66 document [46] were used in (Equation (1)), internally in WEAP, to arrive at potential yield variations.

$$
\left(1-\frac{Y_{a}}{Y_{x}}\right)=K_{y}\left(1-\frac{E T_{a}}{E T_{x}}\right)
$$

Table A3 provides the crop-specific assumptions for $K_{y}$ and potential yields. The $K_{y}$ value of crops was classified into three types. Values $>1,<1$, and $=1$ represent crops that are sensitive to water deficit, more tolerant to water stress, and directly proportional to the change in water availability, respectively. $Y_{x}$ and $Y_{a}$ are the maximum and actual yields, and $E T_{x}$ and $E T_{a}$ are the maximum and actual evapotranspiration, respectively.

It must be noted that this analysis considered only the yield-changes influenced by precipitation and temperature-induced water stress and not from other factors like $\mathrm{CO}_{2}$ fertilization, use of mechanization and fertilizers, and genetic seed modifications, to name a few. Hence, the area of rain-fed agricultural land (crop-specific) was kept constant for improving the tractability of climatic 
impacts in the absence of land-use change. Dale et al. [47] employed a similar procedure in their analysis on climate-change and rain-fed crop yield analysis for Maize production in SSA.

\subsubsection{Climatic Representation}

In this analysis, we used historical data from the global meteorological forcing dataset developed by the hydrology group at Princeton University [48,49]. The dataset provides monthly values for temperature, precipitation, wind speed, and humidity between the years 1948 to 2008 at $0.5^{\circ} \times 0.5^{\circ}$ grid resolution. Since most of the catchments are larger than $2500 \mathrm{~km}^{2}$, all grid points that fell inside a watershed were averaged to calculate a single value for each time step. Figure 2 illustrates the historical mean temperature and precipitation in Uganda.

The selection of future climate scenarios is always a challenge when there is a plethora of general circulation models (GCMs), and each of them developing a projection for the different emission concentration pathways [50]. The latest assessment report from the Intergovernmental Panel on Climate Change (IPCC) - the AR5—is based on results from the different GCM outputs as part of the Fifth Phase of the Coupled Model Inter-Comparison Project (CMIP5). The CMIP5 GCMs analyze four different emission scenarios known as the representative concentration pathways (RCPs), namely 2.6, $4.5,6.0$, and 8.5. Each RCP corresponds to a radiative forcing value $\left(\mathrm{W} / \mathrm{m}^{2}\right)$ in the year 2100 relative to pre-industrial values [51].

In this analysis, we selected two climate change scenarios-one high (RCP 8.5) and a low-medium forcing (RCP 4.5) -from a much broader set that considers climatic projections from multiple GCMs. Since the GCM outputs have different grid resolutions, they were downscaled to a consistent $0.5^{\circ} \times 0.5^{\circ}$ grid resolution. The model outputs, after bias correction, were obtained from two different sources (Boehlert et al. [52] and Hewitson et al. [53]). It must be noted that not all RCP-GCM-bias correction combinations were available from the respective sources.
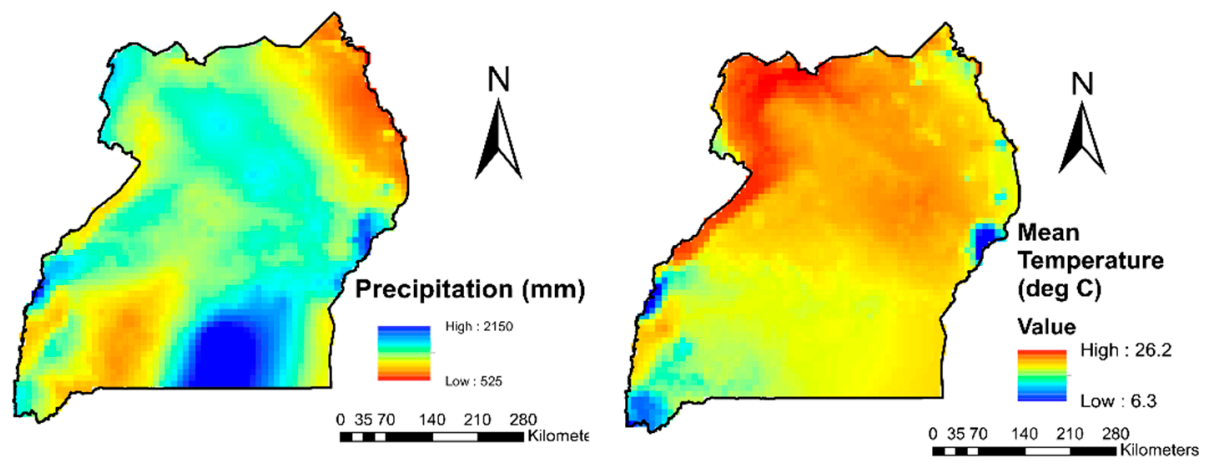

Figure 2. Mean annual precipitation $(\mathrm{mm})$ and average temperature $\left({ }^{\circ} \mathrm{C}\right)$.

Lastly, we ranked the combinations based on their climate moisture index (CMI) [54]. The climate moisture index (CMI) is a measure of aridity that combines the effect of rainfall and temperature projections [55]. Since analyzing all the combinations was outside the scope of this study, we selected two climate change projections - wet and dry-as well as a business as usual (baseline) projection. The cumulatively wettest and driest futures were chosen from the averaged CMI values between 2010 and 2050 for the entire region. Figure 3 illustrates the CMI distribution. The index values varied between -1 and +1 , with lower values representing more arid conditions. A CMI value greater than zero indicated that precipitation rates were greater than potential evapotranspiration rates $[55,56]$. It had to be taken into consideration that the chosen scenarios were cumulatively wet or dry but needed not be in all the years when compared to the baseline. The wettest projection was from the RCP 4.5 scenario of the Beijing Normal University Earth System Model (BNU-ESM) [57]. The driest projection was from the RCP 8.5 scenario of the NASA Goddard Institute for Space Studies model (GISS-E2-H) [58]. 


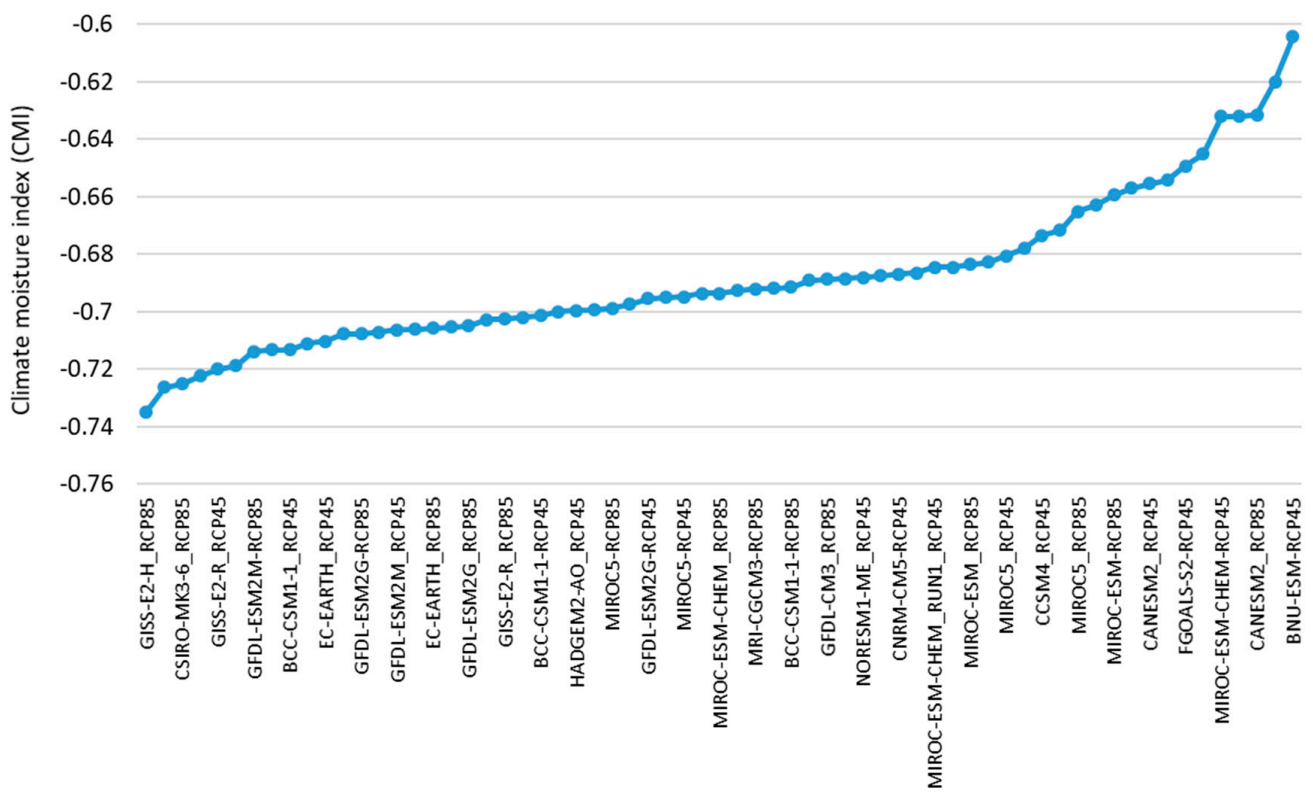

Figure 3. Climate moisture index (CMI) of different available representative concentration pathway-general circulation model (RCP-GCM) combinations. The lower the value of CMI, greater the aridity. The CMI is for the period (2010-2050).

\subsubsection{Demand Representation}

In addition to the water use in crop production (both rain-fed and irrigated lands), we also represented the water consumed in households and by livestock. The methodology (Section S1) and data used for these representations are provided in the Supplementary Materials (Figure S1, Tables S1 and S2).

\subsubsection{Model Calibration}

The developed model was calibrated/correlated on two levels: one between the modelled and historical streamflow at key locations and another for the modelled crop production with country-level FAO statistics. Figure 4 illustrates the calibration that is obtained for the flow out of Lake Victoria at Jinja. The blue and orange lines refer to the modelled and observed outflows from Lake Victoria, respectively.

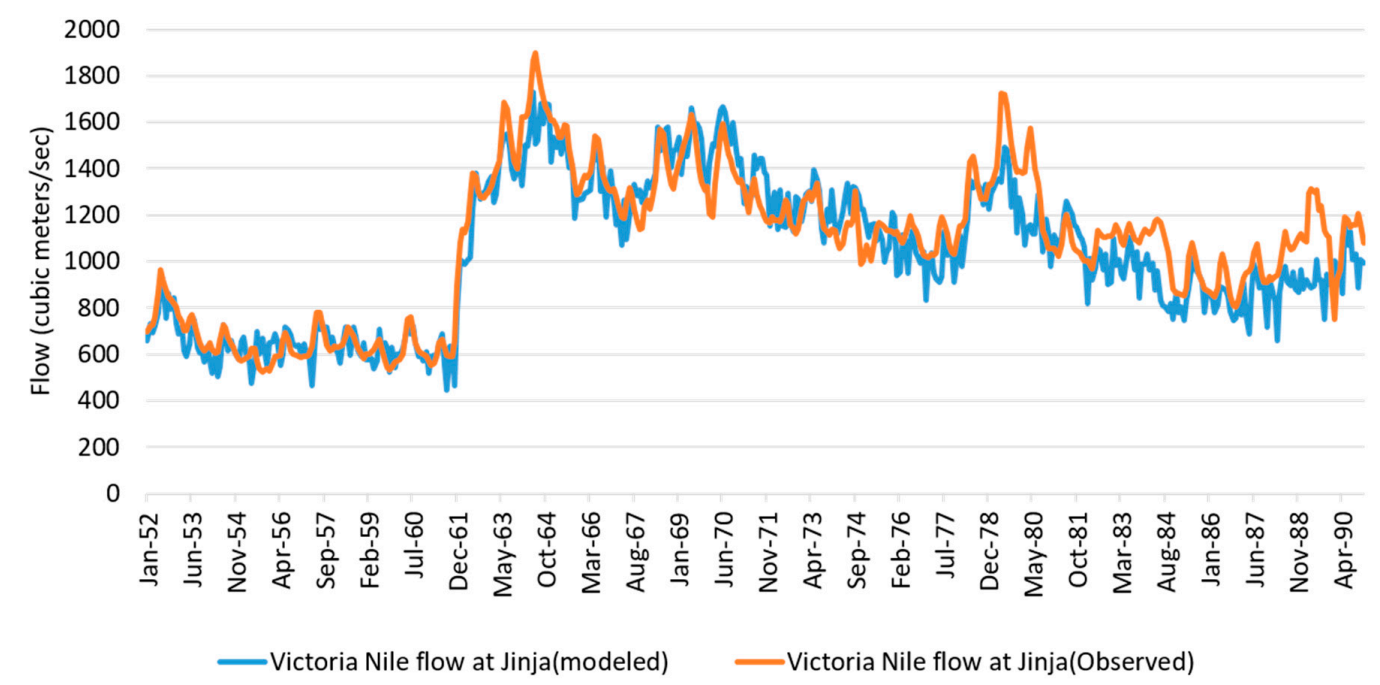

Figure 4. Flow calibration of the water evaluation and planning (WEAP) model at Jinja (the inlet of Lake Victoria into mainland Uganda). 
Supplementary Figures S2-S8 illustrate the correlation obtained between modelled crop production and FAO statistics for seven principal crops identified earlier. Statistical data between 1970 and 1990 was used for the correlation. We calibrated the model to reduce the error between FAO statistics and modelled crop production for the same period. We noticed that staple crops had a better correlation compared to the rest. It must be noted that FAO statistics were reported for both rain-fed and irrigated crop (without a clear distinction) and included non-climatic factors like mechanization, use of fertilizers, etc. The modelled values exhibited only the impact of climate and hence the differences in crop yields compared to reported statistics. That being said, there did exist a bias in the modelled values. Rice crop, for example, is informally irrigated in some managed wetlands, which was reported together with rain-fed production. Hence the difficulty in differentiating them and the subsequent reason for the difference in modelled and actual values. In this model, we tried to separate the rain-fed and irrigated crops to consistently simulate the irrigation master plan.

\subsubsection{Groundwater Representation}

The NWRA estimated a sustainable groundwater abstraction limit for each district in Uganda. The district-specific values were aggregated on a catchment level to be used in the WEAP model (Table A4). This yearly estimate was divided equally among the months and used as maximum withdrawal constraints. The groundwater resource has a higher priority to meet household water demands in most parts of the country, except for big cities like Kampala and Jinja [59]. Kampala and Jinja are supplied by the NWSC directly from Lake Victoria [27]. In this study, we assumed that the water used for irrigation would primarily come from groundwater sources and then be followed by surface water sources. The non-availability of the geolocation of areas irrigated in each catchment was an important factor behind this assumption. The average water table depth (WTD) from Fan et al. [60] was used to calculate the electricity demand for pumping water. Figure 5 illustrates the WTD for the entire country. Catchment specific WTD statistics are provided in Table A5.

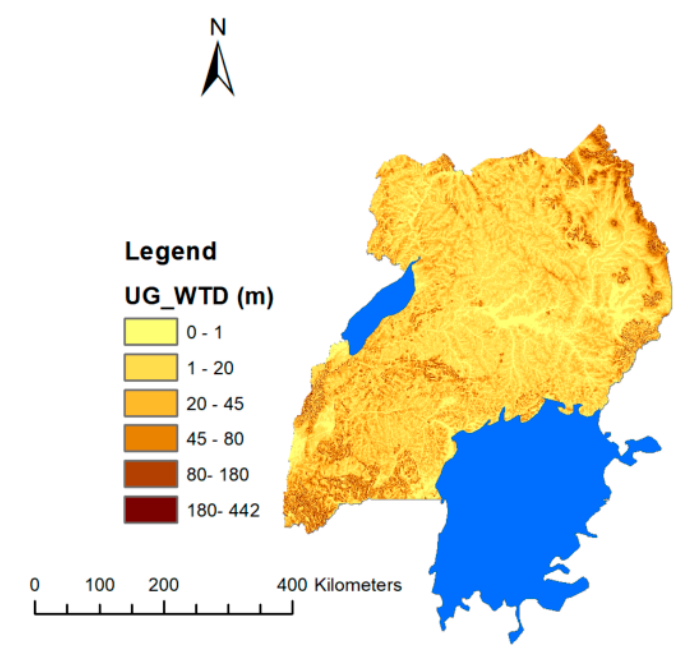

Figure 5. Water table depth (WTD) in m.

\subsubsection{Pumping Electricity Demand}

The demand for electricity to pump water from the ground-though not a significant share of total demand in the country-is of concern in Uganda, where the access to electricity is $\sim 27 \%$. The infrastructure in many parts of the country will need improvement to use electric pumps. Alternatively, diesel pumps can also be used, where transportation of fuel is another aspect that will need streamlining. In this analysis, we assumed that electric pumps will be used for irrigation. The average WTD for each catchment was used to calculate the energy required for lifting water from a certain depth. Figure 6 illustrates the demand for electricity as a function of lift $(\mathrm{m})$ and outlet 
pressure (bar) [61,62]. It must be noted that this study considered only the WTD component of the lift. Considering the cones of depressions [63] that are created by placing two pumps at close intervals was outside the scope of this study. According to the irrigation master plan, a significant share of irrigation is expected to be of sprinkler or drip irrigation types in addition to the open channel system. The pressures required for drip and sprinkler irrigation systems range from 20 to 30 PSI (1.3-2.7 bar) and 30-50 PSI (2-3.4 bar), respectively [64]. In this analysis, we assumed an average discharge pressure of 40 PSI (2.7 bar).

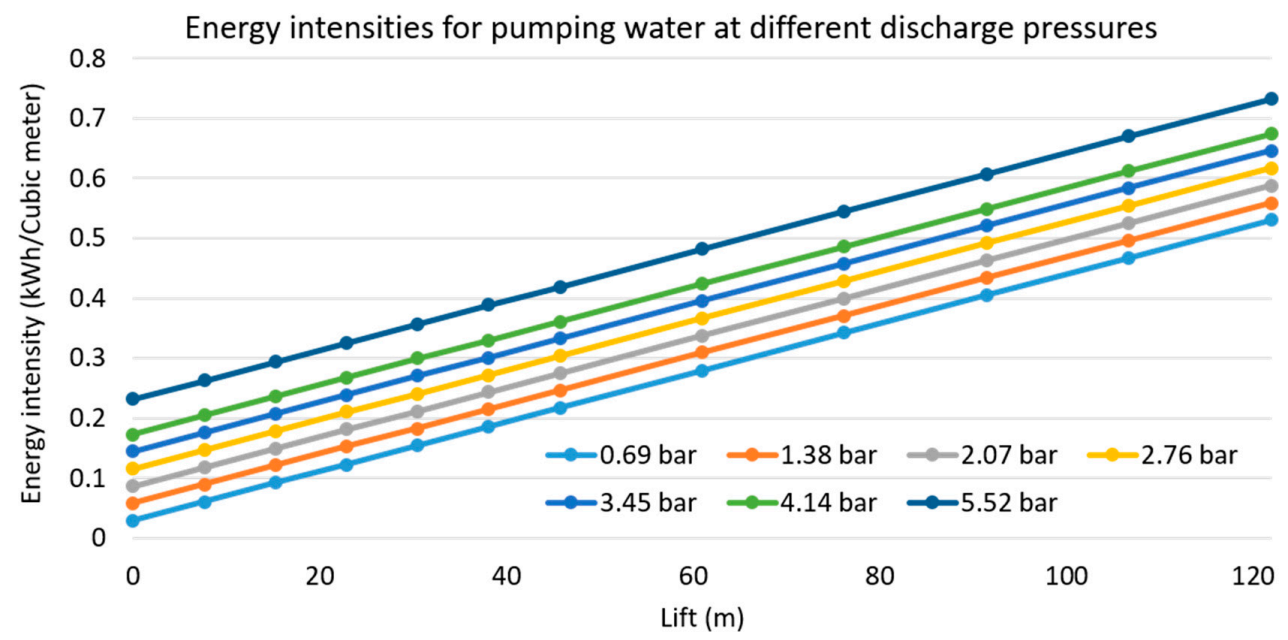

Figure 6. Energy intensity for pumping water (kWh/cubic meter).

\section{Results}

In this section, two main outputs of this analysis are presented.

(i) The yield variations on rain-fed crop production under a baseline and a set of cumulative wettest and driest climatic futures.

(ii) The energy implications of implementing the irrigation master plan (to pump water).

\subsection{Climatic Impacts on Rain-Fed Crop Production}

In this section, we explore the decadal variation in Ugandan rain-fed crop production under the identified driest and wettest climate (cumulatively) futures. The analysis focused on seven major crops (Matooke plantains, cassava, maize, sorghum, coffee, sugarcane, and rice). The main paper discusses the results for principle staple crops: Matooke, cassava, and maize. Table 2 shows the difference in crop production - on a national scale-for the cumulatively wettest and driest climates in comparison to the reference. We noticed that the crops varied in their response to climatic changes but showed a consistent increase in production for the wet scenario. For the driest scenario, there was a reduction in crop production, but the decrease was not as pronounced as the increase in the wettest scenario.

Table 2. Difference in crop production between the reference and selected climate futures.

\begin{tabular}{ccccccc}
\hline \multirow{2}{*}{ Crops } & \multicolumn{3}{c}{ Wettest Comparison } & \multicolumn{3}{c}{ Driest Comparison } \\
\cline { 2 - 7 } & $\mathbf{2 0 2 1 - 2 0 3 0}$ & $\mathbf{2 0 3 1 - 2 0 4 0}$ & $\mathbf{2 0 4 1 - 2 0 5 0}$ & $\mathbf{2 0 2 1 - 2 0 3 0}$ & $\mathbf{2 0 3 1 - 2 0 4 0}$ & $\mathbf{2 0 4 1 - 2 0 5 0}$ \\
\hline Banana & $3.46 \%$ & $8.77 \%$ & $11.37 \%$ & $-8.90 \%$ & $-3.38 \%$ & $-8.19 \%$ \\
Cassava & $3.17 \%$ & $9.76 \%$ & $19.67 \%$ & $-13.51 \%$ & $-5.27 \%$ & $-5.74 \%$ \\
Maize & $6.18 \%$ & $16.78 \%$ & $32.38 \%$ & $-21.39 \%$ & $-9.68 \%$ & $-10.73 \%$ \\
Sorghum & $3.89 \%$ & $11.61 \%$ & $23.20 \%$ & $-14.98 \%$ & $-6.60 \%$ & $-6.34 \%$ \\
coffee & $4.94 \%$ & $13.75 \%$ & $17.71 \%$ & $-11.65 \%$ & $-4.41 \%$ & $-10.11 \%$ \\
rice & $4.68 \%$ & $12.24 \%$ & $24.69 \%$ & $-15.87 \%$ & $-8.18 \%$ & $-7.15 \%$ \\
sugarcane & $5.24 \%$ & $17.06 \%$ & $26.56 \%$ & $-18.30 \%$ & $-8.06 \%$ & $-13.49 \%$ \\
\hline
\end{tabular}


Figures 7-9 illustrate the potential variation in crop production (rain-fed) under the wettest and driest scenarios for three major crops. Each figure has four parts. Parts (a) and (d) highlight the catchment specific differences in crop production in the wettest and driest climate futures and the reference scenario, respectively. The three sub-figures in part (a) and (d) relate to the decades between 2020 and 2050. Part (b) illustrates the production (absolute) in different catchments as of 2017 (modelled) to serve as a reference to differentiate high production regions from the rest. Part (c) gives the modelled yearly production, on a national scale, for three climate futures: the reference, and the cumulatively wettest and driest. It must be noted that parts (a) and (d) should always be interpreted in relation to part (b).

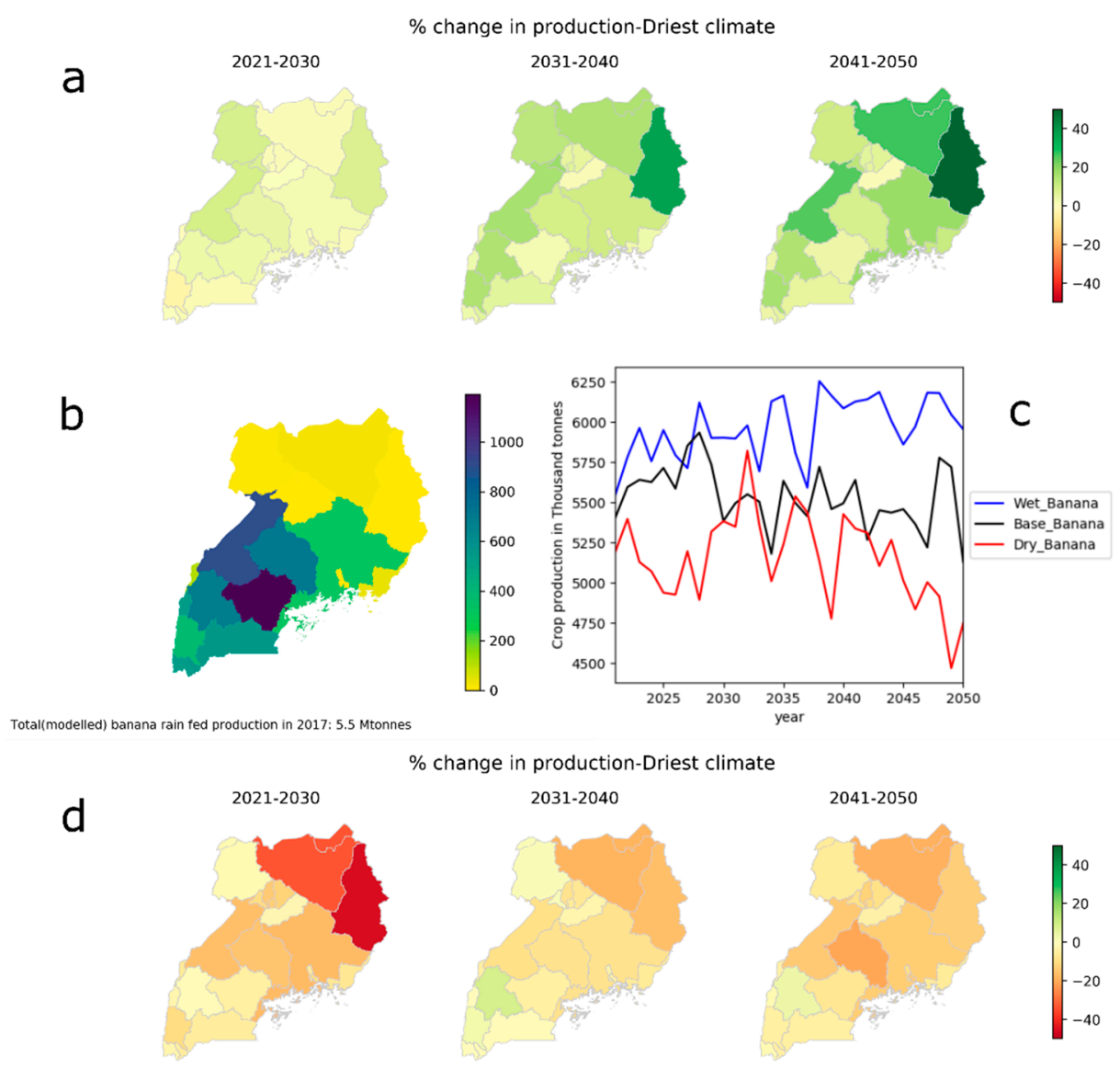

Figure 7. Climatic impact on banana (plantains) production. Catchment specific differences in crop production in the (a) wettest and (d) driest climate futures and the reference scenario is presented. Total modelled (catchment specific) banana production (b) in 2017 is provided to differentiate high production zones from the rest. Parts (a) and (d) should always be interpreted in relation with part $\mathbf{b}$. The line graph (c) provides the annual variation in banana production between the analyzed climate futures on a national level.

In the case of Matooke bananas (plantain), the western and central catchments produced almost all the crop in the country. Hence, a small change in production, especially in the Isingoro, Bushenyi, and Mbarara districts (in the western part of the country), is expected to create a substantial impact on the principal staple food in the country. On the contrary, a significant percentage change in the northern and eastern regions is not expected to make a big difference as they account for less than $2 \%$ of the total plantain production. It must be noted that the driest and the wettest climates were cumulatively dry and wet. We noticed that some catchments in the western region experienced an increase in production in the last two decades under the driest climate future. On a national scale, plantain could suffer a significant reduction in yield in the first decade (about 8-9\%) in the driest 
climate, compared to the baseline, whereas the increase in the wettest scenario is not as pronounced (3-4\%). The last two decades (the $30 \mathrm{~s}$ and $40 \mathrm{~s}$ ) are expected to experience a reversal; the magnitude of yield increase in the wettest scenario is expected to be more pronounced when compared to the decrease in the driest. Figure 8 illustrates the climatic impact on the production of cassava, which is the second most-produced staple crop in the country.

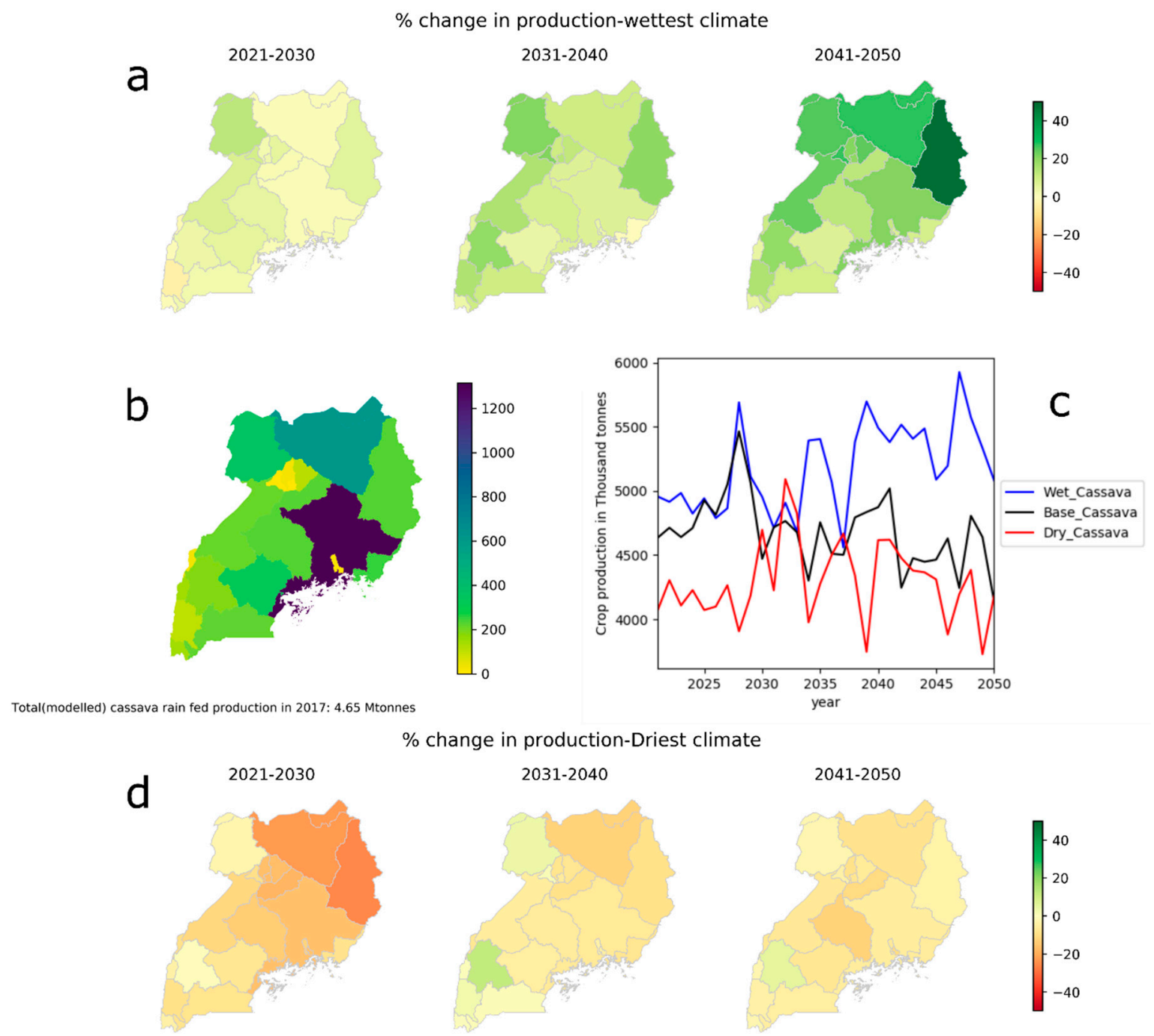

Figure 8. Climatic impact on cassava production. Catchment specific differences in crop production in the (a) wettest and (d) driest climate futures and the reference scenario is presented. Total modelled (catchment specific) cassava production (b) in 2017 is provided to differentiate high production zones from the rest. Parts (a) and (d) should always be interpreted in relation with part (b). The line graph (c) provides the annual variation in cassava production between the analyzed climate futures on a national level.

We noticed that the catchments in the northern and eastern regions produced a significant share-almost two-thirds-of the cassava in the country. Areas around Lake Kyoga, where the share is the highest, could experience a significant reduction under the driest climate. Similar to plantains-on a national scale- the deviation in cassava production under the climatic futures are expected to be more pronounced in the first decade for the driest and the last decade for the wettest future.

Maize, the third most important crop by area harvested and total production, is a staple crop for the urban poor in Uganda and one of the critical staple exports [65]. Cultivated primarily in the eastern and western regions of the country, maize is also a cash crop as it is exported to the neighboring 
DRC, South Sudan, Tanzania, and Kenya. Figure 9 illustrates the climatic impact on rain-fed maize in Uganda. The analyzed climates are expected to produce a broader yield variation in comparison with plantain and cassava, with a significant change expected around Lake Kyoga. It must be taken into consideration that maize is also one of the few crops that is irrigated in Uganda, and the share is only expected to increase.

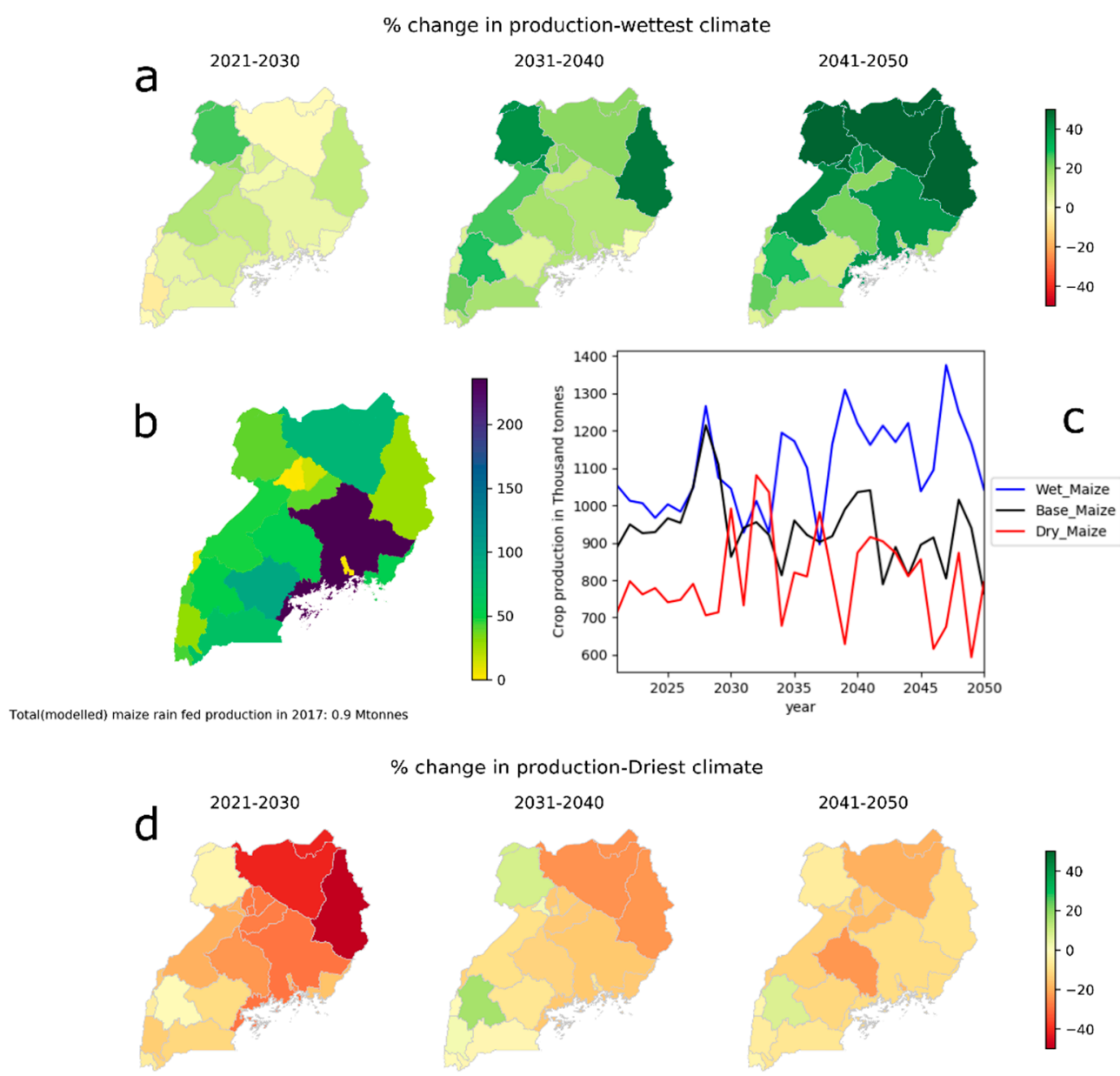

Figure 9. Climatic impact on maize production. Catchment specific differences in crop production in the (a) wettest and (d) driest climate futures and the reference scenario is presented. Total modelled (catchment specific) maize production (b) in 2017 is provided to differentiate high production zones from the rest. Parts (a) and (d)should always be interpreted in relation with part (b). The line graph (c) provides the annual variation in maize production between the analyzed climate futures on a national level.

As part of this analysis, we also analyzed four other crops. Figures S9-S12in the Supplementary Materials illustrate the impact of climatic extremes on coffee, sorghum, rice, and sugarcane. Sugarcane production is expected to have a larger impact in the analyzed futures than on sorghum, rice, and coffee. Coffee, which constitutes approximately $18 \%$ of the total Ugandan exports, is grown at high altitudes (Mount Elgon in the east and the Rwenzori in the West) and some other lower altitude regions. Almost all the coffee in Uganda is rain-fed except for some minor pockets that are drip irrigated. Without a resilient climate plan, a significant share of Ugandan coffee exports could be exposed to the impacts of potential dry futures.

The impact of changes in precipitation and temperature on rain-fed agriculture gives us a glimpse of the food security concerns, especially for the economically poor and arid regions of Uganda where there is limited access to modern machinery, fertilizers, and irrigation facilities. Furthermore, since 
rain-fed agriculture is expected to be the mainstay in Uganda for the foreseeable future, the prospects of a dry climate, could result in a reduction in the seasonal food supply. With the population expected to reach 90 million in 2050, an $8 \%$ decrease in plantain production, owing to a low shelf life period, could increase levels of food insecurity in the country.

The following section highlights the energy (pumping demand) implications of implementing the irrigation master plan.

\subsection{Irrigation and Energy Requirements}

As of 2015, $0.1 \%$ of the total agricultural production comes from irrigated land [11]. The master plan identifies an irrigation potential of about 567,000 ha, which when brought into practice will also warrant for an increase in infrastructure and, specifically, energy-related investments. Uganda is endowed with abundant water resources, but it is also essential to account for their location, seasonality, modes of transportation, and the associated costs when determining their availability. In this article, we estimated the energy requirements for irrigating the crops, as per the master plan, under the identified climatic futures. Figure 10 illustrates the difference in total water requirement for irrigation under the three climate futures, on a national scale. Towards the end of the modelling period, we noticed the difference between the driest and wettest climate, brought about by the increase in land under irrigation and the combination of precipitation and temperature changes in the respective futures.

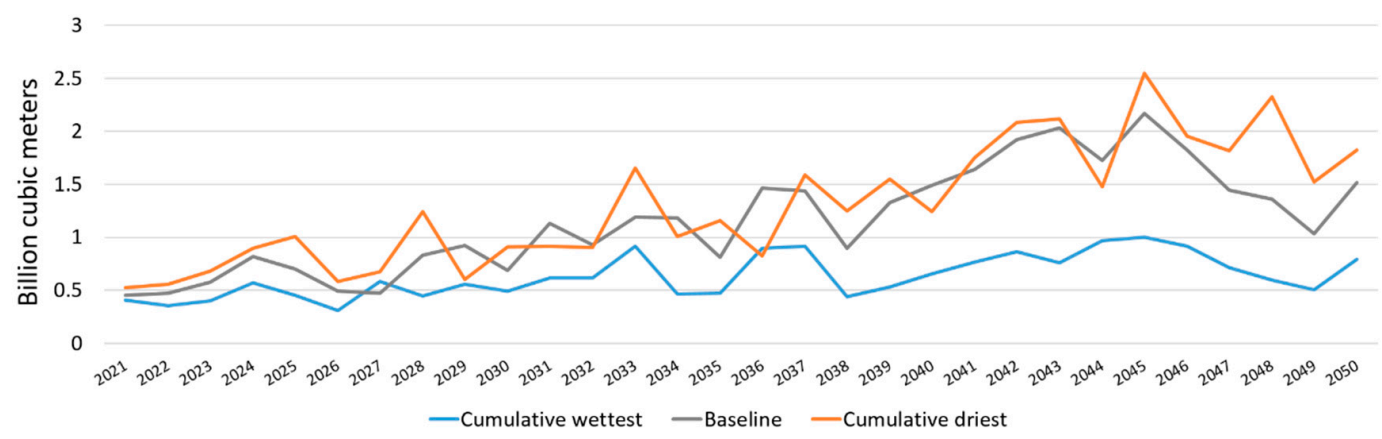

Figure 10. Irrigation water requirements in the analyzed scenarios (billion cubic meters).

The average annual precipitation in the analyzed climate futures is given in Figure 11. We noticed that even the driest climate future had an average annual precipitation of approximately $1000 \mathrm{~mm}$; this is an indication of high rates of evapotranspiration in the country. The water requirement, in these results, is a function of the area that is brought under irrigation in each of the analyzed catchments, type of crop irrigated and the respective localized rates of evapotranspiration. To satisfy this water requirement, we calculated the energy required to pump it from groundwater sources using catchment specific average water table depths.

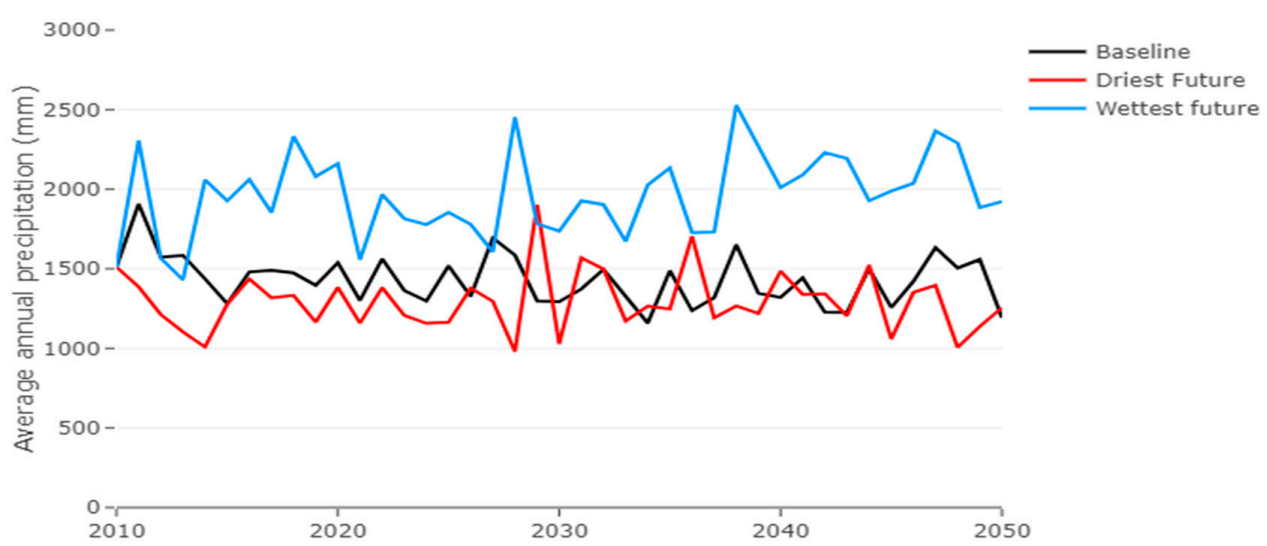

Figure 11. Annual precipitation in the analyzed climate futures (mm/year). 
Figure 12 illustrates the differences in pumping electricity demand. Part (a) indicates the decadal averages of the change in pumping demand in the cumulatively wettest future when compared to the baseline. The zero mark $(0 \%)$ refers to the irrigation pumping demand in the baseline scenario. Part (c) shows the same statistic for the cumulatively driest future. Part (b) presents the catchment specific share of the total pumping demand in the country for the period (2021-2050). Parts (a) and (c) should always be interpreted in relation to part (b).

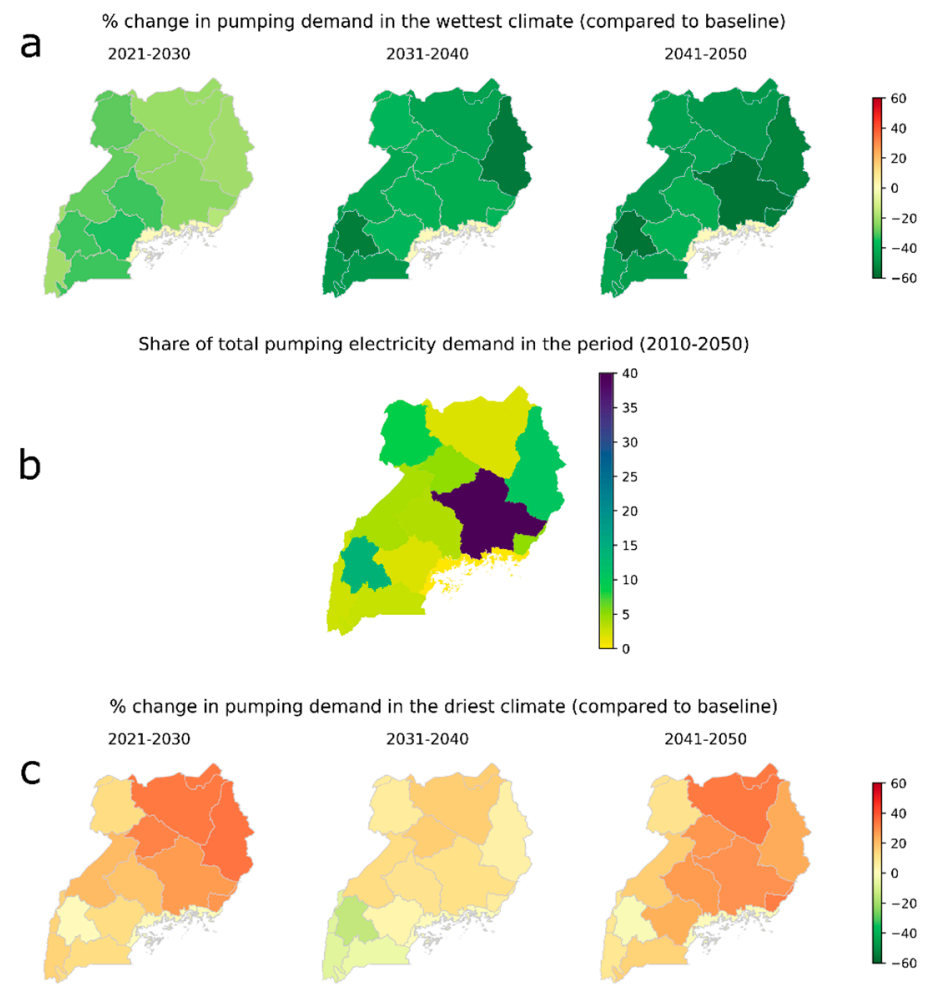

Figure 12. Pumping electricity demand. (a) The decadal average of the change in pumping demand in the cumulatively wettest future when compared to the baseline. (c) The decadal average of the change in pumping demand in the cumulatively wettest future when compared to the baseline. (b) Catchment specific share of the cumulative pumping demand in the country.

It is noticeable that irrespective of the climate, catchments around Lake Kyoga will have the highest share of pumping demand in the country, primarily due to the large area under rice cultivation that is expected to be irrigated. Catchments in the North, near river Aswa, have the lowest demand due to the least share of irrigated area (potential) in the country. Some regions along the shores of Lake Victoria are expected to have lower pumping requirements due to very high precipitation rates and the subsequent reduction in irrigation requirements. Under the cumulatively wettest climate, the pumping requirements are expected to reduce (compared to the baseline) while moving forward in the time, whereas, on the other hand, the demand for the driest climate is expected to reduce in the $30 \mathrm{~s}$ (2031-2040), compared to the $20 \mathrm{~s}$ and $40 \mathrm{~s}$. One notable exception-in the driest climate-is the watershed around Lake George, where the pumping demand in the last two decades is expected to be less than the baseline. This is owing to lower relative change in temperature to the change in precipitation. We estimated that, towards the end of the modelling period, irrigating crops will require approximately $300 \mathrm{GWh}$ of electricity each year in the baseline. The driest scenario is expected to require about $11-12 \%$ more electricity compared to the baseline (for the entire modelling period), which is less severe than what we had expected. This behavior also sheds some light on the choice of studied climate futures. A climate future that is supposed to be cumulatively the driest-based on the average countrywide $\mathrm{CMI}-$ might not be the driest, taking into consideration irrigation water 
requirements and localized change in temperature and precipitation. This aspect must be taken into consideration when choosing climate futures in future studies.

\section{Discussion}

The results from this analysis indicate that despite the cumulative decrease in crop production under the driest climate future and vice-versa in the wettest, yearly variations will play a critical role in meeting local demands and minimum dietary requirements in the country. Uganda, on a national scale, receives abundant precipitation, but its variability and distribution are critical to sustaining crop yields [66]. Bringing areas under irrigation, as identified in the irrigation master plan and the NWRA, is a natural choice considering the amount of renewable water resource in the country. It must be noted that, in this analysis, we considered only four crops (rice, maize, vegetables, and sugarcane) to be irrigated, with rice paddy being the largest by area. Hence, we arrived at a conservative estimate of the total pumping electricity demand. If plantain and the majority of maize cultivated in the country are irrigated, the electricity demand is only expected to increase rapidly. Cassava, being a draught resistant crop (with a $K_{y}<1$ ), is not expected to be irrigated in the near future.

On average, in the reference scenario, to achieve a set yield of $6600 \mathrm{~kg} / \mathrm{ha}$, the plantains are expected to experience a yearly evapotranspiration $(E T)$ shortfall of about $1.8 \mathrm{bcm}$ of water, and this estimate is expected to jump to $2.5 \mathrm{bcm}$ under the driest climate. We must also bear in mind that this estimate is when the expected yield is $6600 \mathrm{~kg} / \mathrm{ha}$. If the expected yield is higher, the ET shortfall and the energy required to pump/transport water to meet crop-water demand will rise sharply, putting a strain on the electricity system. This causes an alarm not only from the point of view on electricity consumption but also from the unsustainable use of water resources, resulting in faster depletion. Another infrastructure-related concern is access to electricity in the country. As of $2016, \sim 27 \%$ of the country has access to electricity (on and off-grid) [67]. Despite the efforts to extend the national grid and the establishment of mini-grid infrastructure to improve electrification, there is no guarantee that the expansion will take agricultural needs as a priority. Alternatively, diesel pumps are also used for irrigation. The difference in diesel and electricity price in the country will be crucial to making a choice. At present, Uganda imports all of its fossil fuel, but the situation could change with the recent oil finds in the Lake Albert region. Moreover, electricity price, which is one of the highest in the region (at present), could drop with better grid infrastructure and reliable electricity generation from hydropower plants. Another possible supply-side solution could be the use of agricultural and crop residues to generate electricity [68].

Another important aspect that was not considered in this analysis is water pricing. Price per unit $\left(\mathrm{m}^{3}\right)$ of pumped water, electricity pricing, and the market value of the irrigated crop will play a crucial role in determining the prospects of irrigation. Fruits, vegetables, and flowers that have a lucrative export market make irrigation feasible/attractive when compared to plantains, which are traded in bulk and primarily in local markets [69]. This analysis implicitly considers wetlands as part of the study but does not explicitly consider rice paddy cultivation in managed wetlands. The master plan estimates that 77,000 ha of managed wetland will be used for paddy irrigation in the medium term but does not consider the impact of climate on wetland areas. According to the NWRA, the wetland conservation policies have been updated after the potentials were calculated, and there could be a situation where the potential might be lower, considering the new regulations.

Moreover, wetlands that have been converted into agricultural lands could result in depletion of water reserves, flash floods, changes in microclimate, reduced fish stocks, and biodiversity losses if not properly managed.

This study estimated the pumping electricity demand under the assumption that all the water is pumped from underground water sources. Uganda is also bestowed with abundant surface water sources, but they are distributed and seasonal (other than the major equatorial lakes and rivers). The geographic scope/scale of this study and the non-availability of potential irrigation sites (geo-location) led us to consider only the groundwater sources for the estimation of electricity demand. Moreover, 
many of Uganda's small rivers are seasonal and do not maintain minimum flows during some months of the year, which might coincide with the crop growing season. That being said, if the hydrological scale of this study is improved to represent the flow in small seasonal rivers and the potential locations for irrigation sites determined, the existing model can be adapted to include the surface water sources. For the question on how the surface water sources will change the picture, it is dependent on the distance of the irrigated sites from the source of water, seasonality of river flows, the proximity of water storage sites, and the gradient between the source and the cropland, to name a few.

In this study, we assumed the mean WTD for each irrigated catchment, calculated using the zonal statistics function of the ArcGIS tool. We noticed that the maximum WTD, considered in this assessment, was around $46 \mathrm{~m}$ (Table A5). The NWRA states that the average borewell depths in the country range between 50 and $106 \mathrm{~mm}$ [27]. Hence, our estimation is expected to be on the conservative side, though many of the borewells are dug deeper from a long term planning perspective.

The results discussed in this article explore only the impact of climatic variables on crop yields/production, which, though significant, is only a part of the story. Crop production is influenced by many other factors like soil type, fertilizer usage, increased mechanizations (tractors), forested area, and fuel-wood usage, to name a few. Epule et al. [70] highlight, from historical records that non-climatic factors like forested area, use of forest wood as fuel, and tractor usage might have a more significant impact on crop production than climatic factors like precipitation and temperature. Despite the existence of a substantial literature regarding climatic impacts on Sub-Saharan crop production, we must process these results with a grain of salt. There is a high probability that the results will differ if the above factors are taken into consideration. Nevertheless, Ugandan agriculture is expected to be of a subsistence type for the near future, and our analysis emphasizes the need to climate-proof crop production to ensure food security.

The choice of climate futures is critical to deriving meaningful insights from climate change impact assessments. Here, we employ a CMI based selection, which has been successfully tested in recent climate change studies $[52,55,56]$. Though an averaged countrywide CMI might be a good indicator for choosing the driest and wettest futures, we find that when analyzing the water requirement for irrigation and the corresponding pumping electricity demand, the selection of climate futures should include more decision variables. The CMI calculation should include the irrigated crop calendar and climatic parameters specific to the irrigated area. Thus, there might not be one single driest or wettest future. There will be a dry or wet combination specific to the area and the crop that is to be irrigated.

Lastly, the uncertainty in climatic projections, though outside the scope of this article, cannot be ignored $[60,61]$. When no real probably exists for the realization of a particular climate future, infrastructure expansion planning-like irrigation and power systems-need some aspects of climate resilience included in early stages of planning. A possible extension of this study could be to analyze the resilience of irrigation expansion plans by considering a broad range of climates and associating some costs of inaction, as implemented by Sridharan et al. [55] for the power sector.

\section{Conclusions}

When analyzing climate change scenarios, it is noticeable that the temperature $\left(T_{\text {mean }}\right)$ gap between the RCP extremes $(2.6$ and 8,5$)$ is evident close to the end of the century $(2100)$ and the deviation starts to become noticeable beginning from the 2040s [71]. However, most of the policy decisions in energy, water, and agriculture-related infrastructure focus on a shorter time frame-the next 10-20 years. This is more relevant in the Sub-Saharan African countries like Uganda, where there is a significant impetus for policies to be climate-resilient, especially in the agricultural and power sectors. The methodology and the insights gained from this study can also be applied to other countries with transboundary water resources where most of the water originates outside its borders. With a combination of heavy hydro dependency, high electricity tariffs, low share of irrigation, and high GW potential, etc., the Ugandan case is also unique in the region. As Uganda embarks on a path to improve its electrification goals and 
at the same time, hold to its emission reduction commitments, the need for non-siloed policies taking into consideration the inter-connections in the WEF systems is all the more relevant.

Supplementary Materials: The following are available online at http://www.mdpi.com/2073-4441/11/9/1805/s1. Figure S1, and Tables S1 and S2 and their corresponding text detail the demand representation in the model. Figures S2-S8 illustrate calibrated model outputs vs FAO statistics, and Figures S9-S12 display the climatic impact on rain-fed crop production (sorghum, rice, cassava, sugarcane). All the data used for this analysis is available from the authors upon request. The catchment definitions have been submitted as shapefiles along with the article.

Author Contributions: Conceptualization, V.S., E.P.R., and E.Z.; methodology, V.S. and E.P.R.; data curation, V.S. and B.B.; writing—original draft preparation, V.S.; writing—review and editing, V.S., B.B., and C.T.; visualization, V.S. and A.S.; supervision, E.Z., M.H., and C.T.; project administration, V.S. and E.Z.

Funding: The models developed for this research work were developed for a project (contract no.: PD/C0165/14) funded by the United Nations Department of Economic and Social Affairs (UNDESA). The authors would also like to thank Formas (The Swedish research council) for supporting this work (contract no.: 942-2015-1304).

Acknowledgments: The authors wish to thank Dimitris Mentis (WRI) and the OnSSET team at KTH-dESA for their guidance in geospatial aspects of this work. We also want to thank Callist Tindimugaya and his team at the Ministry of Water and Environment (MWE) in Uganda for their support during WEAP modelling workshops. We would like to thank Francisco Flores-López (erstwhile at the Stockholm Environmental Institute (SEI)) for his suggestions on WEAP model developments.

Conflicts of Interest: The authors declare no conflict of interest. 


\section{Appendix A}

Table A1. Land cover types in the study area.

\begin{tabular}{|c|c|c|c|c|c|c|c|c|}
\hline Original Catchment Definition & $\begin{array}{l}\text { Aggregated Catchment } \\
\text { Definitions }\end{array}$ & Total Area (Sq. Km) & Forest Land & Grassland & Cropland & $\begin{array}{l}\text { Settlement }+ \\
\text { Other Lands }\end{array}$ & Wetland & Water \\
\hline BJ_Bahr el Jebel upstream Fula & BJ_Bahr el Jebel upstream Fula & 36,687 & $4.66 \%$ & $64.15 \%$ & $29.85 \%$ & $0.39 \%$ & $0.80 \%$ & $0.15 \%$ \\
\hline LA_AlbertNile_Laropi & LA_AlbertNile_Laropi & 17,319 & $11.11 \%$ & $42.53 \%$ & $41.67 \%$ & $0.94 \%$ & $2.37 \%$ & $1.39 \%$ \\
\hline LA_Katonga & LA_Katonga & 13,805 & $13.58 \%$ & $22.16 \%$ & $58.67 \%$ & $0.33 \%$ & $4.01 \%$ & $1.24 \%$ \\
\hline LA_LakeAlbert & LA_LakeAlbert & 24,250 & $18.88 \%$ & $24.58 \%$ & $31.96 \%$ & $1.51 \%$ & $1.30 \%$ & $21.77 \%$ \\
\hline LA_LakeEdward & LA_LakeEdward & 6337 & $15.12 \%$ & $20.14 \%$ & $27.23 \%$ & $0.12 \%$ & $0.05 \%$ & $37.34 \%$ \\
\hline LA_LakeGeorge & LA_LakeGeorge & 10,933 & $16.92 \%$ & $34.86 \%$ & $44.20 \%$ & $0.23 \%$ & $0.76 \%$ & $3.03 \%$ \\
\hline LA_Ntungwe & LA_Ntungwe & 5569 & $17.41 \%$ & $24.61 \%$ & $48.27 \%$ & $0.18 \%$ & $0.36 \%$ & $9.17 \%$ \\
\hline LA_Semliki & LA_Semliki & 4229 & $63.52 \%$ & $15.75 \%$ & $20.11 \%$ & $0.30 \%$ & $0.18 \%$ & $0.15 \%$ \\
\hline $\begin{array}{c}\text { LA__Ruizi } \\
\text { LV_LakeVic_WetArea_West }\end{array}$ & LA_Ruizi & 9989 & $11.63 \%$ & $29.40 \%$ & $51.73 \%$ & $0.44 \%$ & $5.34 \%$ & $1.46 \%$ \\
\hline VN__Agu & VN_Agu & 24,500 & $12.17 \%$ & $64.11 \%$ & $19.40 \%$ & $0.57 \%$ & $3.12 \%$ & $0.64 \%$ \\
\hline VN_Ayago & VN_Ayago & 1489 & $18.89 \%$ & $47.22 \%$ & $33.15 \%$ & $0.03 \%$ & $0.10 \%$ & $0.61 \%$ \\
\hline VN_Isimba & VN_Isimba & 256 & $20.11 \%$ & $0.22 \%$ & $52.27 \%$ & $13.43 \%$ & $1.85 \%$ & $12.12 \%$ \\
\hline VN_Kafu & VN_Kafu & 15,983 & $36.59 \%$ & $19.53 \%$ & $37.51 \%$ & $2.52 \%$ & $3.82 \%$ & $0.03 \%$ \\
\hline VN_Kalagala & VN_Kalagala & 379 & $29.24 \%$ & $0.00 \%$ & $65.99 \%$ & $0.47 \%$ & $0.93 \%$ & $3.37 \%$ \\
\hline VN_Kamdini & VN_Kamdini & 2616 & $3.15 \%$ & $18.44 \%$ & $72.64 \%$ & $1.26 \%$ & $4.17 \%$ & $0.35 \%$ \\
\hline VN_Kiba & VN_Kiba & 418 & $53.51 \%$ & $36.14 \%$ & $7.07 \%$ & $0.08 \%$ & $0.22 \%$ & $2.99 \%$ \\
\hline $\begin{array}{c}\text { LV_LakeVic_WetArea_North } \\
\text { VN_LakeKyoga }\end{array}$ & VN_LakeKyoga & 35,449 & $18.46 \%$ & $5.76 \%$ & $55.16 \%$ & $2.13 \%$ & $9.23 \%$ & $9.26 \%$ \\
\hline $\begin{array}{c}\text { VN_Malaba } \\
\text { LV_LakeVic_WetArea_East }\end{array}$ & VN_Malaba & 13,194 & $18.90 \%$ & $2.06 \%$ & $71.01 \%$ & $0.57 \%$ & $7.26 \%$ & $0.21 \%$ \\
\hline VN_MasindiPort & VN_MasindiPort & 5276 & $16.84 \%$ & $19.48 \%$ & $56.02 \%$ & $1.09 \%$ & $5.84 \%$ & $0.72 \%$ \\
\hline VN_Paraa & VN_Paraa & 1002 & $13.79 \%$ & $81.05 \%$ & $3.76 \%$ & $0.06 \%$ & $0.07 \%$ & $1.27 \%$ \\
\hline
\end{tabular}


Table A2. Irrigation potential.

\begin{tabular}{|c|c|c|c|c|c|c|}
\hline \multirow{2}{*}{ Original Catchment Definition } & \multirow{2}{*}{ Aggregated IRR Catchment Definitions } & \multicolumn{5}{|c|}{ Irrigation Potential (Sq Km) } \\
\hline & & 2010 & 2020 & 2030 & 2040 & 2050 \\
\hline BJ_Bahr el Jebel upstream Fula & BJ_Bahr el Jebel upstream Fula & 2.95 & 23.08 & 43.21 & 91.31 & 167.37 \\
\hline LA_AlbertNile_Laropi & LA_AlbertNile_Laropi & 14.99 & 117.26 & 219.53 & 328.31 & 443.58 \\
\hline \multicolumn{7}{|l|}{ VN_LakeKyoga } \\
\hline VN_Isimba & VN_LakeKyoga & 52.36 & 409.55 & 766.73 & 1169.54 & 1617.97 \\
\hline \multicolumn{7}{|l|}{ VN_Kalagala } \\
\hline VN_Agu & VN_Agu & 19.68 & 153.95 & 288.21 & 459.14 & 666.76 \\
\hline \multicolumn{7}{|l|}{ VN_MasindhiPort } \\
\hline VN_Kamdini & VN_MasindhiPort & 7.53 & 58.90 & 110.27 & 169.49 & 236.56 \\
\hline \multicolumn{7}{|l|}{ VN_Ayago } \\
\hline \multicolumn{7}{|l|}{ VN Kiba } \\
\hline LA_Lake George & LA_Lake George & 17.68 & 138.29 & 258.90 & 379.54 & 500.20 \\
\hline LA_Katonga & LA_Katonga & 2.57 & 20.09 & 37.61 & 66.87 & 107.85 \\
\hline $\begin{array}{l}\text { LA_Lake Albert } \\
\text { LA_Ntungu }\end{array}$ & \multicolumn{3}{|c|}{ LA_Ntungu } & 41.45 & 93.70 & 178.88 \\
\hline LA_LakeEdward & LA_Ntungu & 2.52 & 19.74 & 36.95 & 83.53 & 159.47 \\
\hline \multicolumn{7}{|l|}{ LA_Semliki } \\
\hline LV_LakeVic_WetArea_North & LV_LakeVic_WetArea_North & 4.53 & 35.46 & 66.38 & 102.54 & 143.93 \\
\hline \multicolumn{7}{|l|}{$\begin{array}{c}\text { LA_Ruizi } \\
\text { LV_LakeVic_WetArea_West }\end{array}$} \\
\hline VN_Kafu & VN_Kafu & 4.92 & 38.52 & 72.11 & 132.81 & 220.62 \\
\hline LV_LakeVic_WetArea_East & LV_LakeVic_WetArea_East & 7.01 & 54.79 & 102.57 & 147.61 & 189.89 \\
\hline
\end{tabular}


Table A3. Crop-yield response factors.

\begin{tabular}{ccc}
\hline Crop & Ky Values & Potential Rain-Fed Yield (kg/ha) \\
\hline Banana & 1.35 & 6600 \\
Coffee & 1 & 641 \\
Rice & 1 & 1447 \\
Cassava & 0.9 & 7106 \\
Sugarcane & 1.2 & 60,000 \\
Maize & 1.25 & 1534 \\
Sorghum & 0.9 & 1271 \\
\hline
\end{tabular}

Table A4. Sustainable monthly GW abstraction limit (million cubic meters).

\begin{tabular}{|c|c|c|}
\hline Original Catchment Definition & $\begin{array}{l}\text { Aggregated Catchment } \\
\text { Definition }\end{array}$ & $\begin{array}{l}\text { Sustainable Monthly GW } \\
\text { Abstraction Limit (MCM) }\end{array}$ \\
\hline BJ_Bahr el Jebel upstream Fula & BJ_Bahr el Jebel upstream Fula & 39.95 \\
\hline LA_AlbertNile_Laropi & LA_AlbertNile_Laropi & 47.10 \\
\hline \multicolumn{3}{|l|}{ VN_LakeKyoga } \\
\hline $\begin{array}{l}\text { VN_Isimba } \\
\text { VN_Kalagala }\end{array}$ & VN_LakeKyoga & 114.27 \\
\hline VN_Agu & VN_Agu & 51.70 \\
\hline \multicolumn{3}{|l|}{ VN_MasindhiPort } \\
\hline $\begin{array}{c}\text { VN_Kamdini } \\
\text { VN_Ayago } \\
\text { VN_Kiba }\end{array}$ & VN_MasindhiPort & 36.77 \\
\hline LA_Lake George & LA_Lake George & 29.42 \\
\hline LA_Katonga & LA_Katonga & 22.02 \\
\hline LA_Lake Albert & LA_Lake Albert & 28.34 \\
\hline LA_Ntungu & & 19.49 \\
\hline LA_LakeEdward & LA_Ntungu & \\
\hline \multicolumn{3}{|l|}{ LA_Semliki } \\
\hline VN_Malaba & VN_Malaba & 2.12 \\
\hline LV_LakeVic_WetArea_North & LV_LakeVic_WetArea_North & NA \\
\hline $\begin{array}{c}\text { LA_Ruizi } \\
\text { LV_LakeVic_WetArea_West }\end{array}$ & LA_Ruizi & 24.28 \\
\hline VN_Kafu & VN_Kafu & 25.48 \\
\hline LV_LakeVic_WetArea_East & LV_LakeVic_WetArea_East & NA \\
\hline
\end{tabular}


Table A5. Catchment specific water table depths (WTD).

\begin{tabular}{|c|c|c|c|c|}
\hline Original Catchment Definition & $\begin{array}{c}\text { Aggregated IRR } \\
\text { Catchment Definitions }\end{array}$ & Min WTD (m) & $\operatorname{Max}$ WTD (m) & Mean WTD (m) \\
\hline BJ_Bahr el Jebel upstream Fula & BJ_Bahr el Jebel upstream Fula & 0 & 210.8 & 16.9 \\
\hline $\begin{array}{l}\text { LA_AlbertNile_Laropi } \\
\text { VN_LakeKyoga }\end{array}$ & LA_AlbertNile_Laropi & 0 & 186.5 & 18.7 \\
\hline $\begin{array}{l}\text { VN_LakeKyoga } \\
\text { VN_Isimba } \\
\text { VN_Kalagala }\end{array}$ & VN_LakeKyoga & 0 & 264.6 & 14.4 \\
\hline $\begin{array}{l}\text { VN_Agu } \\
\text { VN_MasindhiPort } \\
\text { VN_Paraa }\end{array}$ & VN_Agu & 0 & 59.8 & 13.7 \\
\hline $\begin{array}{l}\text { VN_Kamdini } \\
\text { VN_Ayago } \\
\text { VN_Kiba }\end{array}$ & VN_MasindhiPort & 0 & 337.1 & 13.0 \\
\hline LA_Lake George & LA_Lake George & 0 & 360.1 & 36.3 \\
\hline LA_Katonga & LA_Katonga & 0 & 407.0 & 18.5 \\
\hline $\begin{array}{l}\text { LA_Lake Albert } \\
\text { LA_Ntungu }\end{array}$ & LA_Lake Albert & 0 & 421.0 & 46.0 \\
\hline $\begin{array}{l}\text { LA_LakeEdward } \\
\text { LA_Semliki }\end{array}$ & LA_Ntungu & 0 & 383.4 & 37.4 \\
\hline VN_Malaba & VN_Malaba & 0 & 147.9 & 9.3 \\
\hline LV_LakeVic_WetArea_North & LV_LakeVic_WetArea_North & 0 & NA & NA \\
\hline $\begin{array}{c}\text { LA_Ruizi } \\
\text { LV_LakeVic_WetArea_West }\end{array}$ & LA_Ruizi & 0 & 407.2 & 43.7 \\
\hline VN_Kafu & VN_Kafu & 0 & 90.7 & 16.9 \\
\hline LV_LakeVic_WetArea_East & LV_LakeVic_WetArea_East & 0 & NA & NA \\
\hline
\end{tabular}

\section{References}

1. Uganda Bureau of Statistics (UBOS). Statistical Abstract 2018; Uganda Bureau of Statistics: Kampala, Uganda, 2019.

2. MAAF; MWE. Uganda: National Irrigation Policy. 2017. Available online: https://www.mwe.go.ug/sites/ default/files/library/Uganda\%20National\%20Irrigation\%20Policy.pdf (accessed on 1 April 2019).

3. Africa-Uganda-The World Factbook-Central Intelligence Agency 2017. Available online: https://www.cia. gov/library/publications/resources/the-world-factbook/geos/ug.html (accessed on 1 April 2019).

4. Mubiru, D.N.; Komutunga, E.; Agona, A.; Apok, A.; Ngara, T. Characterising agrometeorological climate risks and uncertainties: Crop production in Uganda. S. Afr. J. Sci. 2012, 108, 108-118. [CrossRef]

5. Adhikari, U.; Nejadhashemi, A.P.; Woznicki, S.A. Climate change and eastern Africa: A review of impact on major crops. Food Energy Secur. 2015, 4, 110-132. [CrossRef]

6. Villegas, J.R.; Thornton, P.K. Climate Change Impacts on African Crop Production; CGIAR Research Program on Climate Change, Agriculture and Food Security (CCAFS): Frederiksberg, Denmark, 2015.

7. Roudier, P.; Sultan, B.; Quirion, P.; Berg, A. The impact of future climate change on West African crop yields: What does the recent literature say? Glob. Environ. Chang. 2011, 21, 1073-1083. [CrossRef]

8. Wasige, J.E. Assessment of the Impact of Climate Change and Climate Variability on Crop Production in Uganda; Makerere University: Report to Global Change SysTem for Analysis, Research and Training (START)/US National Science Foundation (NFS): Kampala, Uganda, 2009.

9. Bagamba, F.; Bashaasha, B.; Claessens, I.; Antle, J. Assessing climate change impacts and adaptation strategies for smallholder agricultural systems in Uganda. Afr. Crop Sci. J. 2012, 20, 303-316.

10. Waithaka, M.; Nelson, G.C.; Thomas, T.S.; Kyotalimye, M. (Eds.) East African Agriculture and Climate Change: A Comprehensive Analysis; International Food Policy Research Institute (IFPRI): Washington, DC, USA, 2013.

11. Dale, N.; Markandya, A.; Bashaasha, B.; Beucher, O. Economic Assessment of the Impacts of Climate Change in Uganda; Ministry of Water and Environment (MWE): Kampala, Uganda, 2015.

12. MWE. A National Irrigation Master Plan for Uganda (2010-2035); Republic of Uganda Ministry of Water and Environment: Kampala, Uganda, 2011.

13. Harrison, P.A.; Dunford, R.W.; Holman, I.P.; Rounsevell, M.D.A. Climate change impact modelling needs to include cross-sectoral interactions. Nat. Clim. Chang. 2016, 6, 885-890. [CrossRef]

14. Bazilian, M.; Rogner, H.; Howells, M.; Hermann, S.; Arent, D.; Gielen, D.; Steduto, P.; Mueller, A.; Komor, P.; Tol, R.S.; et al. Considering the energy, water and food nexus: Towards an integrated modelling approach. Energy Policy 2011, 39, 7896-7906. [CrossRef] 
15. Howells, M.; Hermann, S.; Welsch, M.; Bazilian, M.; Segerström, R.; Alfstad, T.; Gielen, D.; Rogner, H.; Fischer, G.; Van Velthuizen, H.; et al. Integrated analysis of climate change, land-use, energy and water strategies. Nat. Clim. Chang. 2013, 3, 621-626. [CrossRef]

16. Pereira-Cardenal, S.J.; Madsen, H.; Arnbjerg-Nielsen, K.; Riegels, N.; Jensen, R.; Mo, B.; Wangensteen, I.; Bauer-Gottwein, P. Assessing climate change impacts on the Iberian power system using a coupled water-power model. Clim. Chang. 2014, 126, 351-364. [CrossRef]

17. Hoff, H. Understanding the Nexus. Background Paper for the Bonn2011 Conference: The Water, Energy and Food Security Nexus; Stockholm Environment Institute (SEI): Stockholm, Sweden, 2011.

18. Albrecht, T.R.; Crootof, A.; Scott, C.A. The Water-Energy-Food Nexus: A systematic review of methods for nexus assessment. Environ. Res. Lett. 2018, 13, 043002. [CrossRef]

19. Daher, B.T.; Mohtar, R.H. Water-energy-food (WEF) Nexus Tool 2.0: Guiding integrative resource planning and decision-making. Water Int. 2015, 40, 748-771. [CrossRef]

20. Dai, J.; Wu, S.; Han, G.; Weinberg, J.; Xie, X.; Wu, X.; Song, X.; Jia, B.; Xue, W.; Yang, Q. Water-energy nexus: A review of methods and tools for macro-assessment. Appl. Energy 2018, 210, 393-408. [CrossRef]

21. Endo, A.; Tsurita, I.; Burnett, K.; Orencio, P.M. A review of the current state of research on the water, energy, and food nexus. J. Hydrol. Reg. Stud. 2017, 11, 20-30. [CrossRef]

22. Mukuve, F.M.; Fenner, R.A. The influence of water, land, energy and soil-nutrient resource interactions on the food system in Uganda. Food Policy 2015, 51, 24-37. [CrossRef]

23. Mukuve, F.M.; Fenner, R.A. Scale variability of water, land, and energy resource interactions and their influence on the food system in Uganda. Sustain. Prod. Consum. 2015, 2, 79-95. [CrossRef]

24. FAO. AQUASTAT-FAO's Information System on Water and Agriculture. 2014. Available online: http: //www.fao.org/nr/water/aquastat/didyouknow/index3.stm (accessed on 6 July 2018).

25. Prado, J.; Beare, R.J.; Siwo Mbuga, J.; Oluka, L.E. A Catalogue of Fishing Methods and Gear Used in Lake Victoria; FAO: Rome, Italy, 1991.

26. Frostick, L. Chapter 9 The East African rift basins. Sediment. Basins World 1997, 3, 187-209.

27. MWE. Uganda National Water Resources Assessment; Ministry of Water and Environment (MWE): Kampala, Uganda, 2013.

28. Amaral, M.M.; Herrin, W.E.; Gulere, G.B. Using the Uganda National Panel Survey to analyze the effect of staple food consumption on undernourishment in Ugandan children. BMC Public Health 2017, 18, 32. [CrossRef]

29. FAOSTAT (Food and Agriculture Organization of the United Nations, Statistics Division). Forestry Production and Trade. Available online: http://www.fao.org/faostat/en/\#data/FO (accessed on 4 April 2019).

30. SEI-US. WEAP (Water Evaluation and Planning). 2018. Available online: https://www.weap21.org (accessed on 10 February 2019).

31. Yates, D.; Sieber, J.; Purkey, D.; Huber-Lee, A. WEAP21-A Demand-, Priority-, and Preference-Driven Water Planning Model. Water Int. 2005, 30, 487-500. [CrossRef]

32. Hussen, B.; Mekonnen, A.; Pingale, S.M. Integrated water resources management under climate change scenarios in the sub-basin of Abaya-Chamo, Ethiopia. Model. Earth Syst. Environ. 2018, 4, 221-240. [CrossRef]

33. Bhave, A.G.; Conway, D.; Dessai, S.; Stainforth, D.A. Water Resource Planning Under Future Climate and Socioeconomic Uncertainty in the Cauvery River Basin in Karnataka, India. Water Resour. Res. 2018, 54, 708-728. [CrossRef]

34. Blanco-Gutiérrez, I.; Varela-Ortega, C.; Purkey, D.R. Integrated assessment of policy interventions for promoting sustainable irrigation in semi-arid environments: A hydro-economic modeling approach. J. Environ. Manag. 2013, 128, 144-160. [CrossRef]

35. Mulligan, M.; Fisher, M.; Sharma, B.; Xu, Z.; Ringler, C.; Mahe, G.; Jarvis, A.; Ramírez, J.; Clanet, J.-C.; Ogilvie, A.; et al. The nature and impact of climate change in the Challenge Program on Water and Food (CPWF) basins. Water Int. 2011, 36, 96-124. [CrossRef]

36. Faiz, M.A.; Liu, D.; Fu, Q.; Li, M.; Baig, F.; Tahir, A.A.; Khan, M.I.; Li, T.; Cui, S. Performance evaluation of hydrological models using ensemble of General Circulation Models in the northeastern China. J. Hydrol. 2018, 565, 599-613. [CrossRef]

37. Sun, L.; Pan, B.; Gu, A.; Lü, H.; Wang, W. Energy-water nexus analysis in the Beijing-Tianjin-Hebei region: Case of electricity sector. Renew. Sustain. Energy Rev. 2018, 93, 27-34. [CrossRef] 
38. Vanuytrecht, E.; Raes, D.; Steduto, P.; Hsiao, T.C.; Fereres, E.; Heng, L.K.; Vila, M.G.; Moreno, P.M. AquaCrop: FAO's crop water productivity and yield response model. Environ. Model. Softw. 2014, 62, 351-360. [CrossRef]

39. Jones, J.; Hoogenboom, G.; Porter, C.; Boote, K.; Batchelor, W.; Hunt, L.; Wilkens, P.; Singh, U.; Gijsman, A.; Ritchie, J.; et al. The DSSAT cropping system model. Eur. J. Agron. 2003, 18, 235-265. [CrossRef]

40. Kling, H.; Gupta, H. On the development of regionalization relationships for lumped watershed models: The impact of ignoring sub-basin scale variability. J. Hydrol. 2009, 373, 337-351. [CrossRef]

41. Breinl, K. Driving a lumped hydrological model with precipitation output from weather generators of different complexity. Hydrol. Sci. J. 2016, 61, 1395-1414. [CrossRef]

42. Santikayasa, I.P.; Babel, M.S.; Shrestha, S. Assessment of the Impact of Climate Change on Water Availability in the Citarum River Basin, Indonesia: The Use of Statistical Downscaling and Water Planning Tools. In Managing Water Resources under Climate Uncertainty; Shrestha, S., Anal, A.K., Salam, P.A., van der Valk, M., Eds.; Springer International Publishing: Cham, Switzerland, 2015; pp. 45-64.

43. Li, J.; Oyana, T.J.; Mukwaya, P.I. An examination of historical and future land use changes in Uganda using change detection methods and agent-based modelling. Afr. Geogr. Rev. 2016, 35, 1-25. [CrossRef]

44. Mwanjalolo, M.G.J.; Bernard, B.; Paul, M.I.; Joshua, W.; Sophie, K.; Cotilda, N.; Bob, N.; John, D.; Edward, S.; Barbara, N. Assessing the Extent of Historical, Current, and Future Land Use Systems in Uganda. Land 2018, 7, 132. [CrossRef]

45. UBOS. Uganda Census of Agriculture 2008/2009: Crop Area and Production Report VOL IV; Uganda Bureau of Statistics: Kampala, Uganda, 2011.

46. Steduto, P.; Hsiao, T.C.; Fereres, E.; Raes, D. Crop Yield Response to Water; FAO: Rome, Italy, 2012.

47. Dale, A.; Fant, C.; Strzepek, K.; Lickley, M.; Solomon, S. Climate model uncertainty in impact assessments for agriculture: A multi-ensemble case study on maize in sub-Saharan Africa. Earths Futur. 2017, 5, 337-353. [CrossRef]

48. Sheffield, J.; Goteti, G.; Wood, E.F. Development of a 50-Year High-Resolution Global Dataset of Meteorological Forcings for Land Surface Modeling. J. Clim. 2006, 19, 3088-3111. [CrossRef]

49. Terrestrial Hydrology Research Group: Princeton University. Available online: http://hydrology.princeton. edu/home.php (accessed on 1 August 2016).

50. Knutti, R.; Sedláček, J. Robustness and uncertainties in the new CMIP5 climate model projections. Nat. Clim. Chang. 2013, 3, 369-373. [CrossRef]

51. Taylor, K.E.; Stouffer, R.J.; Meehl, G.A. An Overview of CMIP5 and the Experiment Design. Bull. Am. Meteorol. Soc. 2011, 93, 485-498. [CrossRef]

52. Boehlert, B.; Strzepek, K.M.; Groves, D.; Hewitson, B.; Jack, C. Climate Change Projections in Africa-Chapter 3. In Enhancing the Climate Resilience of Africa's Infrastructure: The Power and Water Sectors; The World Bank: Washington, DC, USA, 2016; p. 219.

53. Hewitson, B.C.; Daron, J.; Crane, R.G.; Zermoglio, M.F.; Jack, C. Interrogating empirical-statistical downscaling. Clim. Chang. 2014, 122, 539-554. [CrossRef]

54. Willmott, C.J.; Feddema, J.J. A More Rational Climatic Moisture Index. Prof. Geogr. 1992, 44, 84-88. [CrossRef]

55. Sridharan, V.; Broad, O.; Shivakumar, A.; Howells, M.; Boehlert, B.; Groves, D.G.; Rogner, H.-H.; Taliotis, C.; Neumann, J.E.; Strzepek, K.M.; et al. Resilience of the Eastern African electricity sector to climate driven changes in hydropower generation. Nat. Commun. 2019, 10, 302. [CrossRef]

56. Cervigni, R.; Liden, R.; Neumann, J.E.; Strzepek, K.M. Enhancing the Climate Resilience of Africa's Infrastructure: The Power and Water Sectors; The World Bank: Washington, DC, USA, 2016.

57. Ji, D.; Wang, L.; Feng, J.; Wu, Q.; Cheng, H.; Zhang, Q.; Yang, J.; Dong, W.; Dai, Y.; Gong, D.; et al. Description and basic evaluation of Beijing Normal University Earth System Model (BNU-ESM) version 1. Geosci. Model Dev. 2014, 7, 2039-2064. [CrossRef]

58. Schmidt, G.A.; Kelley, M.; Nazarenko, L.; Ruedy, R.; Russell, G.L.; Aleinov, I.; Bauer, M.; Bauer, S.E.; Bhat, M.K.; Bleck, R.; et al. Configuration and assessment of the GISS ModelE2 contributions to the CMIP5 archive. J. Adv. Model. Earth Syst. 2014, 6, 141-184. [CrossRef]

59. Directorate of Water Development; Ministry of Water \& Environment; Republic of Uganda. Uganda Water Supply Atlas 2017. Available online: http://www.wateruganda.com/index.php/reports/national (accessed on 8 January 2017).

60. Fan, Y.; Li, H.; Miguez-Macho, G. Global Patterns of Groundwater Table Depth. Science 2013, 339, $940-943$. [CrossRef] 
61. Plappally, A.K.; Lienhard, V.J.L. Energy requirements for water production, treatment, end use, reclamation, and disposal. Renew. Sustain. Energy Rev. 2012, 16, 4818-4848. [CrossRef]

62. Martin, D.L.; Dorn, T.W.; Melvin, S.R.; Corr, A.J.; Kranz, W.L. Evaluating energy use for pumping irrigation water. In Proceedings of the 23rd Annual Central Plains Irrigation Conference, Burlington, CO, USA, 22-23 February 2011; pp. 22-23.

63. Şen, Z. Chapter 4-Unconfined Aquifers. In Practical and Applied Hydrogeology; Şen, Z., Ed.; Elsevier: Oxford, UK, 2015; pp. 209-278.

64. How to Determine Pressure \& Flow in Sprinklers \& Irrigation Systems. Available online: https://www. sprinklerwarehouse.com/DIY-Determine-Pressure-and-Flow-s/6671.htm (accessed on 26 February 2019).

65. USAID; Chemonics International Inc. Uganda-Staple Food Market Fundamentals; FEWS NET (Famine Early Warning Systems Network): Kampala, Uganda, 2017.

66. Épule, T.E.; Ford, J.D.; Lwasa, S.; Nabaasa, B.; Buyinza, A. The determinants of crop yields in Uganda: What is the role of climatic and non-climatic factors? Agric. Food Secur. 2018, 7, 10. [CrossRef]

67. The World Bank. Access to Electricity (\% of Population). Available online: http://data.worldbank.org/ indicator/EG.ELC.ACCS.ZS (accessed on 18 July 2017).

68. Okello, C.; Pindozzi, S.; Faugno, S.; Boccia, L. Bioenergy potential of agricultural and forest residues in Uganda. Biomass Bioenergy 2013, 56, 515-525. [CrossRef]

69. Maslin, M.; Austin, P. Uncertainty: Climate models at their limit? Nature 2012, 486, 183-184. [CrossRef]

70. Weaver, A.J.; Zwiers, F.W. Uncertainty in climate change. Nature 2000, 407, 571-572. [CrossRef]

71. Core Writing Team; Pachauri, R.K.; Meyer, L.A. Climate Change 2014: Synthesis Report; Contribution of Working Groups I, II and III to the Fifth Assessment Report of the Intergovernmental Panel on Climate Change; IPCC: Geneva, Switzerland, 2014.

(C) 2019 by the authors. Licensee MDPI, Basel, Switzerland. This article is an open access article distributed under the terms and conditions of the Creative Commons Attribution (CC BY) license (http://creativecommons.org/licenses/by/4.0/). 